\title{
When the Kids Live at Home: \\ Coresidence, Parental Assets, and Economic Insecurity
}

\author{
May 2017 \\ Forthcoming in Journal of Marriage and Family
}

Michelle Maroto ${ }^{1}$

University of Alberta

\begin{abstract}
ACKNOWLEDGEMENTS
This research was partially supported by a Social Sciences and Humanities Research Council (SSHRC) Insight Development Grant (\#430-2014-00092).
\end{abstract}

${ }^{1}$ Department of Sociology, University of Alberta, 6-23 Tory Building, Edmonton, AB, Canada, T6G 2H4, maroto@ualberta.ca 


\title{
When the Kids Live at Home: Coresidence, Parental Assets, and Economic Insecurity
}

\begin{abstract}
This study uses National Longitudinal Survey of Youth 1979 cohort data from 1994 through 2012 ( $\mathrm{N}=16,108$ person-years, 4,671 individuals) to investigate how coresidence with adult children influences asset levels among parents. It applies hybrid mixed effects regression models that partition between- and within-person variation to estimate parental savings and financial assets over time and across different households. The results suggest that coresidence with adult children led to decreases in parental assets and savings. In the years in which their children lived at home, parents held $24 \%$ less in financial assets and $23 \%$ less in savings compared to years when adult children were not present. By expanding previous research that shows a relationship between increasing economic insecurity, limited wealth, and the rise in coresidence among young adults, this study also offers broader implications for the interconnectivity of financial hardship across generations.
\end{abstract}

\section{KEYWORDS}

Coresidence; Family Economics; Inequality; Intergenerational Transfers; National Longitudinal Survey of Youth (NLSY) 


\section{INTRODUCTION}

In recent decades, changing norms and expectations, as well as higher levels of economic insecurity, have elongated the transition to adulthood with younger adults now passing certain milestones like marriage and homeownership at much later ages than their parents (Seltzer \& Bianchi, 2013). As a result, young adults in the United States have become more reliant on parents for financial and non-financial support throughout this transition, and many have been opting to reside within their parents' households for longer periods of time (Kornrich \& Furstenberg, 2013). Coresidence or “doubling up" has been particularly widespread among millennials, the youngest cohort of adults born in the 1980s and 90s, due, in part, to their rising debt levels and precarious employment situations (Bleemer et al., 2014; Dettling \& Hsu, 2014; Wiemers, 2014). Although coresidence and other types of parental support can help to improve the economic situations of young adults, the continued reliance of adult children on parents could potentially have lasting effects for parental resources and economic wellbeing, which warrants additional research into the consequences for parents. More specifically, questions remain as to whether coresidence stands out as a type of parental support with stronger effects on parental resources than other types of planned wealth transfers.

To address this situation, I study coresidence among millennial young adults over age 18 and their parents who, in many cases, were born during the later years of the post-WWII baby boom. Instead of simply studying situations of the children, I investigate how coresidence with adult children might influence the financial assets and savings of these late baby boomer cohort parents. In doing so, I address the following research questions: How might continued coresidence with adult children affect parental assets and parents' levels of economic security more broadly? How do parental assets fluctuate when adult children live at home, and how do 
coresidential households compare to those with adult children living outside the home or at school?

Although research on the implications of coresidence for young adults has been growing, few, if any, studies have examined the consequences of coresidence for the parents. This study addresses this gap in research by using longitudinal data from the 1979 cohort of the National Longitudinal Survey of Youth (NLSY79; http://www.bls.gov/nls/nlsy79.htm) to investigate changes in assets and savings over time. In particular, I use hybrid mixed effects models to parse out the within- and between-person asset effects of adult children living in the household. The within-person effects compare parental assets and savings in the years where adult children are present to the years where they are not, and the between-person effects compare average asset differences between individuals who do and do not live with their adult children. This allows me to examine differences across individuals, controlling for key factors that include income, education, and family structure, and to study changes within individual assets and savings over time net of unobserved individual-level characteristics.

I specifically focus on how adult children in different living situations -- those currently present in the household, those not present but who usually reside in the household, those who live at school, and those who are not present in the household -- influence whether parents report any financial assets and savings and their total financial assets and savings. These variables reflect a family's capacity to save and the effects of changes in day-to-day expenses, two central components of economic security that are likely related to the presence of adult children in the household and elsewhere. Among parents of adult children, I expect that the presence of children in the household will have the strongest negative effects on savings because of the costs associated with children living at home. 
My results support this expectation. Across models, coresidence with adult children, much more than having adult children living elsewhere, was negatively associated with financial assets and savings among parents. In the years in which their children lived at home, parents held $24 \%$ less in financial assets and $23 \%$ less in savings compared to years when adult children were not present. Given that households with adult children generally have lower assets than those without, my findings help to illustrate how much of this transfer of wealth occurs when adult children are living at home.

This study contributes to research on life course transitions, intergenerational inequality, and economic insecurity by showing how continued housing assistance for adult children limits parental resources. By combining broader perspectives that acknowledge the complexities of intergenerational inequality with theories related to life course transitions and economic insecurity, I am able to highlight the interconnectivity of assets, debt, and financial hardship across generations. Moreover, the recent rise in multigenerational living arrangements, as more young adults have been moving into their parents' homes to deal with rising economic insecurity, makes this topic particularly relevant. Debt, particularly in the form of student loans, presents one factor as to why many young adults have been moving home (Bleemer et al., 2014). When this also creates financial hardship and reduces parental assets through their continued support, economic insecurity spreads from adult children to their parents. Therefore, to complement studies that have focused on the pathways extending from parent resources to child wellbeing, this study demonstrates how disadvantage can move in the other direction, stretching from adult children to their parents. 


\section{BACKGROUND}

\section{Changing Life Course Transitions and Increasing Economic Insecurity}

With the growth of divorce, cohabitation, and single parenthood, family demographers have long since moved beyond a uniform model for the family life cycle (Cherlin, 2010). Most acknowledge that the pathways to adulthood have also become quite varied for young adults since the 1960s. Many of these young adults no longer engage in a linear progression through major life course transitions, such as leaving the parental home, obtaining a full-time job, marrying, and having children of their own (Sironi \& Furstenberg, 2012). Instead, the transition to adulthood and independence has lengthened with increased education, housing, and transportation costs (Furstenberg, 2010; Goldscheider \& Goldscheider, 1999a, 1999b; Swartz, 2008, 2009). These trends are also associated with the spread of economic insecurity, which refers to the "risk of economic loss faced by workers and households as they encounter the unpredictable events of social life" (Western et al., 2012, p. 342).

In addition to addressing the relationship between risk and changing life course transitions among young adults, studies of economic insecurity often place families and households at the center of stratification processes to demonstrate how economic wellbeing depends on the social context within which an individual is embedded (Western et al., 2012). Family dynamics become central to individual wellbeing in this model, similar to Elder's (1985, 1994) linked lives principle, which ties individual life trajectories to family and household members (Macmillan \& Copher, 2005). The stagnation of wages since the 1970s and a declining social safety net, spurred by cuts to government spending and policies, such as the Personal Responsibility and Work Opportunity Reconciliation Act of 1996 (PRWORA), have all 
contributed to increasing economic insecurity, which is felt by individuals and their family members (Cancian \& Haskins, 2014; Hacker, 2006; McCloud \& Dwyer, 2011).

This situation is particularly relevant for the millennial generation, whose members are currently between the ages of 13 and 33. Millennial young adults, as a cohort, have been experiencing greater economic insecurity than their parents, which has been motivating the rise in coresidence among this group (Sironi \& Furstenberg, 2012). They face lower wages, fewer available jobs, and higher rates of unemployment (Taylor, 2014). In addition to these labor market factors, millennial young adults are more indebted than previous generations with a larger proportion of debt coming from student loans and non-secured debt (Dwyer, McCloud, \& Hodson, 2011; Houle, 2014). This has affected life course transitions, such as marriage and parenthood, among youth who are waiting longer to attain these milestones (Addo, 2014; Bozick \& Estacion, 2014; Dettling \& Hsu, 2014; Nau, Dwyer, \& Hodson, 2015). Increasing economic insecurity is also associated with coresidence with parents at the state- and individual-levels (Mykyta \& Macartney, 2010; Wiemers, 2014). Because family member trajectories are linked I expect that this less secure path into adulthood will also influence outcomes for parents as financial insecurity is passed up from the younger generation.

\section{Intergenerational Support and Coresidence in Parental Households}

Both the elongated transition toward adulthood and the rise in economic insecurity largely coincide with increased parental support and the growth of coresidence among parents and adult children. As a result of these combined factors, parental support for and spending on young adult children has risen over time (Kornrich \& Furstenberg, 2013). It now presents an important, perhaps even necessary, component for children's wellbeing where approximately 
one-third to one-half of adult youth living independently have received financial support from their parents (Fingerman et al., 2012; Settersen \& Ray, 2010). In supporting their children into adulthood, parents offer material assistance through the transfer of money, goods, and housing (Schoeni \& Ross, 2005; Seltzer \& Bianchi, 2013). Many pay for schooling and its associated costs (Rauscher, 2016) and some even use their home equity to finance higher education (Lovenheim, 2011). Parents also provide time and attention, especially in the form of unpaid childcare (Folbre, 2012), moral encouragement, and advice (Swartz, 2008). With these many types of financial and non-financial transfers, housing is just one of the ways in which parents provide support for their adult children.

Coresidence between adult children and their parents has become much more common since the 1980s. Today, young adults remain in their parents' homes for longer than in the past, and they are also more likely than ever to move back into parental homes after leaving (Fry \& Passel, 2014; Taylor, 2014). In 2015, 55\% of young adults between the ages of 18 and 24 lived with their parents, representing an $11 \%$ increase in rates of coresidence since 2005 (U.S. Census, 2015). Among young adults aged 25 to 34, there was a $40 \%$ increase in the proportion living in parental homes since 2005; ten years later $15 \%$ of young adults in this age group resided with their parents (U.S. Census, 2015). In addition, using 1997 NLSY cohort data, Dey \& Pierret (2014) found that even though $90 \%$ of young adults had moved out of their parents' homes for at least three months by age $27,55 \%$ had also moved back home by the same age. These findings mirror earlier studies, which estimated that approximately $40-50 \%$ of young adults returned home after their initial departures (Aquilino, 1996; Goldscheider \& Goldscheider, 1999b; Swartz, 2009).

Even with increasing rates of coresidence, parental support does vary with the needs and 
circumstances of the children (Schoeni \& Ross, 2005; Swartz et al., 2011). Parents tend to increase their assistance for young adult children who experience adverse events, such as job loss, divorce, and illness (Fingerman et al., 2009, 2012; Smits, van Gaalen, \& Mulder, 2010). Children whom parents deem as more "deserving," especially students enrolled in university studies, also tend to receive greater support (Fingerman et al., 2009, 2012; Seltzer \& Bianchi, 2013; Swartz et al., 2011). This means that asset-declines in coresidential households might stem from supporting children as they deal with financial hardship or as they work towards upward mobility. Additionally, the amount and type of assistance provided differs across families (Schoeni \& Ross, 2005). Parents with higher incomes and education provide more overall resources to their children, but coresidence is more common among low-income and racial minority families who lack other resources to share (Fingerman et al., 2015; Hardie \& Seltzer, 2016; Seltzer \& Bianchi, 2013). Beyond the need to share resources, higher rates of coresidence among racial minority and immigrant families also stem from cultural preferences (Albertini \& Kohli 2013; Hardie \& Seltzer, 2016; Kamo 2000; Van Hook \& Glick, 2007). In these situations, coresidence might not necessarily drain parental resources, as increased support and coresidence are more normative occurrences. Thus, whereas the components of and reasons for support might vary across families, most young adults now receive some form of parental assistance in their transition to adulthood.

\section{Benefits and Drawbacks of Coresidence}

As one of the major forms of parental support, coresidence can offer a variety of benefits, including resource pooling, emotional comfort, and monetary savings for young adults (Bianchi et al., 2007; Glick \& Van Hook, 2011; Swartz, 2009). For instance, using Fragile Families and 
Wellbeing Study data, Pilkauska, Garfinkel, and McLanahan (2014) found that mothers in doubled-up households saved an average of $\$ 4,000$ per year on rent compared to other mothers with similar characteristics, and they saved $\$ 4,600$ per year compared to what they paid when they were not doubled-up. This does not include additional savings associated with economies of scale in larger households, either. Extended household living arrangements have also been particularly important to disadvantaged and economically vulnerable groups that include single parents, young adults, and racial minorities (Glick \& Van Hook, 2002), which explains why members of these groups are more likely to double up (Mykyta \& Macartney, 2010).

Although it is often complicated to untangle the reasons as to how extended households form (Cohen \& Casper, 2002), coresidence with adult children most often occurs due to the needs of the children (Aquilino, 1990; Choi, 2003; Smits et al., 2010; Ward, Logan, \& Spitze, 1992). For instance, although both generations' support needs mattered in Smits, van Gaalen, and Mulder's (2010) study of coresidence in the Netherlands, the needs of the children still outweighed the needs of the parents in coresidential decisions. Economic situations matter greatly in these decisions. In Seltzer, Lau, and Bianchi's (2012) vignette study, participants were also more likely to describe coresidence as desirable in times of financial hardship.

Regardless of the child's experiences of economic hardship, this type of parental support is generally expected, even with elongated transitions to adulthood (Goldscheider, Thornton, \& Yang, 2001; Yelowitz, 2007). The goal of independence for young adults then becomes a joint enterprise, where parents take on the struggles of their children (Swartz et al., 2011). Having parental help can be incredibly beneficial for young adult children, but parents also provide resources at a cost to their own financial wellbeing, especially if they are already in precarious financial situations (Settersen \& Ray, 2010; Swartz et al., 2011). Under such circumstances, 
extending aid to struggling family members can burden those who supply resources, limiting savings and overall wealth.

\section{Wealth, Assets, and Intergenerational Inequality}

Research on intergenerational inequality and mobility in sociology has traditionally studied how individuals' labor market positions relate to those of their parents, while attempting to determine intergenerational correlations for income and patterns of association for class positions across generations (Blau \& Duncan, 1976; Erikson \& Goldthorpe, 1992, 2002). More recently, Mare (2011) and others (Pfeffer, 2014) have argued for a broader view of mobility processes, which considers the complex social relations that exist across multiple generations, as well as the many components of class position. I combine this perspective with theories related to life course transitions and economic insecurity in order to highlight the bi-directionality of financial hardship and family support in relation to wealth, assets, and savings. I also seek to address the larger implications of continued parental support for adult children.

Wealth transfers are an integral component of intergenerational inequality and mobility processes. There is much evidence to demonstrate how intergenerational processes related to inheritance pass down advantages and disadvantages through families (Avery \& Rendall, 2002; Spilerman, 2000; Wolff, 2002). Inheritances in the form of financial and non-financial intergenerational transfers directly link economic positions across generations, providing the children of wealthier parents with an advantage over other families (Spilerman, 2000). Even though much inequality exists in parents' ability to support children and transfer wealth, parents with the means to do so often make as series of planned wealth transfers to their adult children throughout the life course (Fingerman et al., 2015; Hardie \& Seltzer, 2016; Seltzer \& Bianchi, 
2013). These parents might pay for higher education and provide gifts for certain life events, such as weddings and graduations, and down payments for new homes. Coresidence, however, is an event that is not always planned for that can lead to added and unexpected daily costs.

Supporting children into adulthood is expensive, and even more costly for youth who live at home. Living with adult children directly inflates consumption costs within the household, as food and utility bills increase. Parents can also become responsible for paying additional bills incurred by their adult children. Using earlier PSID data from 1988, Schoeni and Ross (2005) estimated that the average family spent approximately $\$ 4,500$ to $\$ 5,000$ per year supporting youth between the ages of 18 to 34 who lived at home, but for youth living independently, family support averaged between $\$ 1,000$ and $\$ 1,700$ per year. In such situations, the negative effects of coresidence should be most apparent in changes in parental assets, especially within financial and liquid assets, as parents draw on savings to make ends meet.

Previous studies indicate that support for adult children will likely lead to decreases in parental wealth, but more recent data are needed to better gauge the magnitude of these effects, determine whether relationships hold net of other covariates, and study the types of assets that might be affected. Although the effects of coresidence on total wealth may take time to appear, as families take on new debts and sell assets, the effects on liquid assets should be more immediate. For these reasons, I expect that coresidence with adult children will be associated with decreases in parental assets and savings in the years where adult children are present in the household compared to the years where they are living elsewhere. I also expect the declines to be largest for the years when adult children are present, as opposed to the years where they reside elsewhere or at school. 
It is important to note that the consequences of coresidence are not necessarily bad for all parties involved. Supporting adult children through financial and non-financial transfers can drain parental savings, but it also likely improves the economic situations of these children. Norms regarding nuclear family households and preferences for independent living make living with parents a less desirable option (Amato et al., 2007; Fingerman et al., 2015), but coresidence still presents a variety of benefits, including increased economic security for the guest parties (Swartz, 2009). This further implies a bi-directionality to processes of intergenerational inequality. Although parents can pass on assets to improve situations for their adult children, this process can also work in the opposite direction, compounding disadvantage for parents who support their struggling children into adulthood, many of whom are increasingly in debt themselves (Bleemer et al., 2014; Dettling \& Hsu, 2014).

\section{METHOD}

Data

I use data from the 1979 National Longitudinal Survey of Youth to study the relationship between coresidence with adult children and parental assets. The NLSY79 cohort is a stratified sample of 12,686 respondents who were between 14 and 22 years old when first surveyed in 1979. These respondents consist of members of the later baby boomer generation, born between 1957 and 1964. The on-going survey interviewed respondents annually from 1979 through 1992, and biennially from 1992 through 2012. In addition to containing ample information on demographics, family transitions, employment, and education, the survey has also collected wealth information from respondents since 1985, which it further expanded and revised in 1994 to cover more specific forms of assets and debt. 
Because I focus on financial assets and savings, I rely on seven survey waves for 1994, 1996, 1998, 2000, 2004, 2008, and 2012, which are the years where the NLSY collected asset data. In creating this time restriction, I also removed most of the military and low-income oversamples, which the survey stopped re-interviewing in 1985 and 1991. This reduced my sample to 9,289 individuals. I then restricted the sample to individuals who reported living in their own dwelling in order to ensure that I only included households where the adult children moved in with a host respondent. Studies of household transitions often have trouble determining which household members are guests and which are hosts (Cohen \& Casper, 2002) and which respondents are in charge of household decision-making (Steele, Clarke, \& Washbrook, 2013). In these relationships, hosts, who have some sources of independence, have greater resources than guests, who do not have homes of their own (Cohen \& Casper, 2002). To primarily capture hosts, I excluded respondents living in their parents' households, dormitories, military barracks, prison, or other institutions, which reduced the sample to 9,200 individuals.

I next restricted the sample to respondents who were at least 33 years old and who were parents of at least one adult child age 18 and older, which included those who resided with a spouse or partner's children. After removing non-parents, missing data, cases with assets greater than $\$ 2$ million, and individuals with only one observation, a sample of 4,761 individuals (or cases) and 16,108 observations (or person-years) remained. My data, therefore, take the form of an unbalanced panel sample in which the number of time periods may differ across individuals.

\section{Outcome Variables}

I examine four outcome variables related to total financial assets and savings, which allow me to determine how coresidence might affect wealth through the limiting of different 
assets. Financial assets include the total value of stocks, CDs, tax-deferred savings, and regular savings in 2012 U.S. dollars. I then examine savings as a separate outcome measure because it is the most common financial asset that families invest in and have access to. Savings refers to the total monetary value of checking and savings accounts in 2012 dollars. My four variables include whether the respondent reported any financial assets and any savings and the respondent's logged financial assets and logged savings.

The first column in Table 1 presents weighted descriptive statistics across person-years for the full sample. Across years, $80 \%$ of individuals reported some financial assets and $73 \%$ reported some savings. However, only $47 \%$ reported owned financial assets other than regular savings accounts and even fewer specifically reported owning any stocks or CDs. The average financial assets were $\$ 75,000$ and average savings were $\$ 15,000$. These variables also had respective median values of $\$ 7,800$ and $\$ 1,700$ across all observations, including those with zero assets and savings.

\section{[Table 1]}

\section{Predictor Variables}

My primary predictor variable measures the presence of adult children age 18 and older in the household. This variable, which I constructed using household roster information, includes biological and adopted children of the respondent or the respondent's partner and refers to adult children reported as currently living in the household. Between 1994 and 2012, 36-43\% of parents reported the presence of adult children in the household each year, and the majority of individuals lived with their adult children at some point. Seventy-seven percent of parents spent at least one year residing with their adult children. 
I also used questions related to the current residence of each child to better represent other living situations and potential levels of dependence on parents. I include a variable to account for whether the respondent has any adult children who usually resided at home, but were not present at the time of the interview. I also include a variable to indicate whether the adult child usually resides "away at school" to evaluate whether the costs of adult children might derive from schooling. Thus, my comparison or referent group is households with adult children who are not currently or usually present and not at school, which allows me to discuss how wealth varies for individuals with adult children in different living situations.

As shown in Table 1, which presents descriptive statistics by the presence of adult children in the household, $40 \%$ of observations had adult children present, $14 \%$ included adult children who usually resided at home but were not present, $6 \%$ had adult children residing at school, and $39 \%$ had adult children who were not currently or usually present or at school. Furthermore, parents with adult children present were often doing as well or better than those without adult children present. They reported higher earnings and were more likely to be married and employed than other individuals. These parents also appeared to hold more in financial assets and savings than those without adult children present. However, although average differences existed across households, questions remain as to how adult children affect assets over time within the same household.

\section{Control Variables}

I include time-varying covariates for demographic, employment, health, family, and regional variables to account for different explanations of wealth inequality. Because assets vary with age and household structure (Lupton \& Smith, 2003; Spilerman, 2000; Yamokoski \& 
Keister, 2006; Zagorsky, 2005), I control for the respondent's reported age and marital status. I measure age in years and include a quadratic age-squared term in order to account for any nonlinear relationships with assets. Marital status indicates whether the respondent was married (the referent), never married, or formerly married (separated, divorced, or widowed).

I further account for aspects of household structure by including variables for the number of adults in the household and the number of biological or adopted children under 18 years of age in the household. Although younger children likely have negative effects on assets, previous students have presented mixed results for the relationship between young children and wealth (Grinstein-Weiss et al., 2008). Because family needs and living costs vary by location, I include an indicator variable for the respondent's residence in a rural area. I also control for the presence of health limitations, which could influence the respondent's ability to work, need to draw from savings, or propensity to ask for support from other household members.

In addition to demographic factors, education, employment, and income have generally shown a positive association with assets (Bricker et al., 2014; Semyonov \& Lewin-Epstein, 2013). I therefore include measures for the respondent's employment status and cumulative number of job gaps, as well as the combined total wage and salary income of the respondent and the respondent's partner. Employment status is a categorical variable that indicates whether the respondent was employed full-time (referent), employed part-time, or not employed during the previous calendar year. I measure a respondent's cumulative number of job gaps lasting eight weeks or more using a categorical variable with the following categories: no job gaps (the referent); a single job gap; and two or more job gaps. I control for the respondent and spouse's logged total earnings from wages and salary from the previous year in 2012 U.S. dollars. This 
variable includes income from tips, bonuses, and overtime pay in order to more accurately represent earnings.

In addition to its connections to wealth, education is also related to economic security, higher rates of marriage, and lower rates of multigenerational living (Cancian \& Haskins, 2014; Kalmijn, 2013; Western et al., 2012). I therefore control for the respondent's school enrollment status and education level. Enrollment status is a dichotomous variable. I measure education as the number of completed years of schooling because that is how the NLSY collected education information. Finally, because homeownership is the largest component of wealth for most households (Spilerman, 2000), I also include a variable to indicate whether the respondent was a homeowner.

I include time-invariant covariates for the respondent's sex, measured as male or female, and race/ethnicity. Race/ethnicity is a categorical variable measured as non-Hispanic white (referent), non-Hispanic black, and Hispanic. These controls help to account for the lower asset levels and higher rates of coresidence among racial minority households, which stem from cultural preferences and broader barriers (Swartz, 2009). Because respondents with adult children likely had children at younger ages in this cohort sample, I also control for age at first child, which measures the age at which the respondent first became a parent. In addition to these time-invariant covariates, I also designate the survey wave year. The survey-year variable is an indicator variable with seven categories where the referent is the most recent wave (2012). I include this variable to account for any unobserved period effects. 


\section{Analytical Models}

I use hybrid mixed effects (HME) models with fixed effects for time-varying covariates and random effects for time-invariant covariates to investigate asset disparities (Allison, 2009). These models take the form of random effects models that account for correlated disturbance terms for the same person over time by assigning each person a separate intercept (Allison, 2009; Gelman \& Hill, 2007). I incorporate fixed effects for time-varying covariates within each model by expressing these variables as deviations from their person-specific means, which represent the within-person variation over years. I also include the person-specific means in order to provide estimates based on the average between-person variation, net of time-varying and time-invariant covariates. By incorporating both factors into each model, I am able to discuss the variation in assets for an individual in the sample (or the average of the average change in assets for an individual over time) as well as the variation in average assets across similar individuals. This allows me to control for unobserved, stable, time-invariant, individual-level characteristics, assess the effects of time-varying and time-invariant factors, and address selection into certain statuses (Allison, 2009). HME models, therefore, help to overcome the limitations of separate fixed and random effects models, but they provide estimates consistent with both procedures.

Equation 1 represents the general random effects model for continuous data, which I use to estimate and individual's total logged financial assets and savings at time, $t$. I also use a similar equation within a logit model to estimate whether an individual reported any financial assets or any savings at time, $t$.

$$
\log \left(y_{i t}\right)=\mu_{t}+\beta X_{i t}+\gamma Z_{i}+\alpha_{i}+\varepsilon_{i t}
$$


where $i$ indexes the individual respondent and $t$ indexes yearly observations per individual. In this equation, $\mu_{t}$ represents the time-varying intercept, $\gamma Z_{i}$ represents vectors of the timeinvariant coefficients and predictor variables, $\beta X_{i t}$ represents vectors of the time-varying coefficients and predictor variables, and $\varepsilon_{i t}$ is the error term that represents random variation at each point in time. These models assume that $\alpha_{i}$, which is treated as a set of random variables with a specified probability distribution, is independent of all other variables in the model.

I then partition the within- and between-person variation through person-specific meancentering of the time-varying predictors in equation 1 (Allison, 2009). For dichotomous variables the person-specific mean refers to the proportion of cases in the category coded as one. Equation 2 illustrates this process,

$$
x_{i t}^{*}=x_{i t}-\bar{x}_{i}
$$

where $x_{i t}^{*}$ represents the person-mean centered time-varying covariate, $x_{i t}$ is the original score for individual $i$ at time $t$, and $\bar{x}_{i}$ represents the person-specific mean for individual $i$. I then incorporate both the person-specific deviations and means into my final model, as shown in Equation 3:

$$
\log \left(y_{i t}\right)=\mu_{t}+\beta X_{i t}^{*}+\left(\gamma_{1} \bar{X}_{i}+\gamma_{2} Z_{i}\right)+\alpha_{i}+\varepsilon_{i t}
$$

Within this model, $\beta X_{i t}^{*}$ represents vectors of the within-person (fixed effects) coefficients and the person-mean-centered time-varying covariates, $\gamma_{1} \bar{X}_{i}$ represents vectors of the between-person (random effects) coefficients and the person-specific-means of time-varying covariates, and $\gamma_{2} Z_{i}$ represents vectors of the time-invariant coefficients and predictor variables. I also include an autoregressive disturbance term with $\varepsilon_{i t}$ to account for the correlation of errors within time series data. 


\section{RESULTS}

Across my results, coresidence with adult children was negatively associated with parental assets, much more than the presence of adult children outside the household. Although, on average, parents who resided with their adult children did not hold lower assets than those who never resided with adult children, these parents saw their assets and savings decrease during the years in which their children lived at home. This indicates that much of the broader effects of adult children on assets are partly driven by the costs to supporting adult children within the parental household.

\section{Financial Assets}

Table 2 presents the results from HME models predicting any financial assets (Model 1) and logged total financial assets (Model 2) in relation to the presence of adult children inside and outside the home. This table divides results into within- and between-person coefficients in order to compare changes in individual assets over time and average asset differences across similar individuals.

\section{[Table 2]}

Beginning with the between-person coefficients in the bottom panel of Table 2, on average, there were no significant differences in financial assets between households who did and did not reside with their adult children, after accounting for income, education, and age at first child. This was true for situations where the adult child was currently at home or usually resided at home. However, households where the adult child usually resided at school generally had much greater assets that those with children residing elsewhere. On average, they were 14 
percent more likely to report assets and held 5 times more in assets than individuals not residing with their adult children. This indicates that sending adult children "away to school" is likely a privilege only available to very wealthy households.

In terms of the within-person differences, financial assets varied over time in relation to the presence of adult children within the household, as shown by the coefficients in the top panel of Table 2. Compared to the years without adult children present, younger baby boomers were no less likely to report any financial assets when adult children lived in the household, net of unobserved time-invariant individual-level characteristics and time-varying covariates (Model 1). However, parents did hold less in financial assets when adult children were present in the household. Coresidence was associated with a decrease of $24.2 \%$ in financial assets (Model 2), but having adult children who usually lived at school did not lead to a specific decrease in assets during those years. This supports Schoeni and Ross's (2005) findings, which showed greater costs associated with providing for adult children living in the home.

In addition to the presence of adult children in the household, other family and household structure variables were also significantly associated with financial assets. Never married and formerly married individuals held less in assets than married individuals and, among those whose marital statuses changed throughout the survey, marriage was associated with greater assets in the years in which they were married. Across years, the number of adults and young children in the household did not present any significant effects on assets, net of other covariates, but, on average, households with more children present had fewer assets. This shows that the presence of adult children, not simply the presence of any children or additional family members in the household, specifically led to asset declines. It also demonstrates why the results of previous 
research regarding the relationship between children and wealth (Grinstein-Weiss et al., 2008) have been so mixed.

Many other control variables were also associated with financial assets. Employment status, income, and homeownership presented some of the strongest between- and within-person associations. Racial and ethnic differences were also apparent. On average, non-Hispanic black parents and Hispanic parents were less likely than non-Hispanic white parents to own any financial assets. Asset levels were also 53\% lower for black parents and 40\% lower for Hispanic parents.

\section{Savings}

To expand on the findings in Table 2, Table 3 presents the results from HME models predicting any savings (Model 1) and logged total savings (Model 2) in relation to the presence of adult children inside and outside the home. This table divides results into within- and between-person coefficients in order to compare changes in individual savings over time and average savings differences across similar individuals.

\section{[Table 3]}

The results for models estimating savings in Table 3 mirror those estimating financial assets in Table 2. There were few significant differences in savings between households with and without adult children present in them, except in the case of households with adult children away at school. Total savings did, however, vary over time in relation to the presence of adult children within the household. Within-parents over time, households with adult children present were no 
less likely to report any savings in the years when they were living with these children than in the years when they were not (Model 1), but parents did report less in savings when adult children were present (Model 2). Compared to the years without adult children, coresidence was associated with a decrease of $23 \%$ in savings, net of unobserved time-invariant individual-level characteristics and other time-varying covariates. Having adult children who usually resided at home but were not currently present did not lead to decreases in savings.

Other household structure variables, such as family size and marital status, were again associated with this outcome. In addition, the number of young children in the household was only significantly associated with between household savings. Finally, employment status, income, homeownership, race, and ethnicity were also associated with reporting any savings and the amount in savings. On average, non-Hispanic black parents held $65 \%$ less in savings than non-Hispanic white parents and Hispanic parents held 44\% less.

\section{DISCUSSION}

Previous studies show that heightened economic insecurity and a more elongated transition to adulthood have increased the need for parental support among young adults (Schoeni \& Ross, 2005; Sironi \& Furstenberg, 2012; Wiemers, 2014). In this study, I extend this research to highlight how coresidence -- one of the most common forms of parental support -can create negative consequences for parental assets and savings. Individuals who extended their households to their adult children experienced financial asset declines of $24 \%$ and savings declines of $23 \%$ in the years when adult children were present in the household, even after accounting for changes in family size. At the mean level of assets, approximately $\$ 33,700$ when 
all variables were held at their means, this was equivalent to an $\$ 8,100$ decrease. For families with average savings of $\$ 3,200$, this was equivalent to a $\$ 710$ decrease.

Parents assist their adult children through different financial transfers for education and other expenses, including general gifts and inheritances; however, housing is the only resource that many have to offer, which factors into the rising rates of coresidence among parents and adult children (Seltzer \& Bianchi, 2013). Previous studies show that unemployment and increasing debt levels among young adults are associated with the rise in multigenerational households (Bleemer et al., 2014; Wiemers, 2014). This study then demonstrates how coresidence with adult children, which most often results from the child's financial hardship, negatively affects assets and savings among the later-baby-boomer cohort. In assessing both outcomes, I was also able to highlight the type of asset -- savings in regular checking and savings accounts -- that is most affected by coresidence. Because savings are easier to access and fluctuate more than other assets, such as stocks and CDs, the effects of coresidence were more pronounced with this asset component. Importantly, savings are also the most common financial asset type across households.

Overall, my results provide support for coresidence with adult children as both a cause and a consequence of economic insecurity. Due to the use of cross-sectional data, most studies of household structure and assets have not been able to fully assess issues of selection into coresidence. For example, many are left asking the question - does coresidence with adult children decrease assets or are less well-off households more likely to reside with their children? Unlike previous studies, the use of HME models allows for a better assessment of the relationship between certain factors. By analyzing between-person coefficients, I was able to discuss issues of selection and demonstrate differences across individuals controlling for key 
covariates associated with assets. By also including within-person coefficients that controlled for all unobserved time-invariant individual-level characteristics, therefore studying changes within individual assets over time, I was able to show that living with adult children decreased assets and savings. Without counterfactual cases (i.e., outcomes for identical persons who never resided with their adult children) with whom I can compare asset outcomes, I cannot truly infer causality in my findings, but my results still offer strong evidence for such a relationship between coresidence and parental assets.

Although my use of longitudinal data and HME regression models helps to better identify between- and within-person differences, my analyses also have certain limitations related to data availability and modeling. Due to my use of NLSY79 data, my results primarily apply to baby boomer adults who were between 47 and 56 years of age in 2012. This limits the generalizability of my findings, but it does allow for a specific discussion of the relationship among millennials and baby boomer parents born between 1957 and 1964. My findings are particularly relevant in relation to literature on millennials' labor market struggles and changing life course transitions. Several recent studies have documented how escalating debt and economic insecurity have increased coresidence among millennials and their baby boomer parents. This study builds on those to demonstrate the consequences for parental assets.

Studying household dynamics also presents more general limitations. As noted by Steele, Clarke, and Washbrook (2013), it can be hard to determine who moves in with whom and what each household member's circumstances are. To help address these issues, my analyses focused on one individual within a household, even through I am interested in the broader relationship between household structure and assets. This helps to simplify the analyses while still providing information about variation across household structures. Restricting the sample to individuals in 
their own dwellings, also helped to identify host parents and guest children, a key component in determining who moves in with whom. Still, it did not allow for a specific identification for why the children moved back into their parents' homes, what their financial situations were like, and whether they were enrolled in school, variables that would be an asset to a study such as this one.

Despite these limitations, this study offers multiple contributions to the literature on life course transitions, economic insecurity, parental support, and intergenerational mobility. Most previous studies of intergenerational mobility have focused on comparing occupational and class standing across two to three generations with the question of -- how are children doing compared to their parents and grandparents? Though informative, these studies do not always acknowledge the interdependences among family members and the instability of income and wealth across lifetimes. By combining this perspective with literature on life course studies and economic insecurity, I present a more complex process where the financial hardship of younger generations can create limitations for those above them.

Whether they live at home or not, raising children and supporting them into adulthood is expensive, even if this is part of a broader system of wealth transfers. According to supplemental analyses that included both parents and non-parents (available upon request), households with adult children living at home or residing elsewhere, with the exception of adult children living at school, held much less in savings and assets compared to those without adult children. On average, they held 59-72\% less in financial assets and savings when compared to otherwise similar individuals without adult children.

Although differences between parents who did and did not reside with adult children were not significant once I accounted for age at first childbirth, the presence of adult children in the household drained parental resources among those who did extend their households and 
likely delved into savings accounts to help aid their children in times of financial distress. This creates a dilemma for parents. Many want to help support their children, but extending support can be hard when it increases day-to-day consumption needs and limits personal assets. Members of this baby boomer cohort are also relatively young, which means that they will still need savings for retirement and their own living costs. Persistent norms of familialism, however, indicate that parents will likely continue to extend resources to their children, even if they must do so at their own expense.

Recent research has focused on the consequences of the recession and growing economic insecurity for millennial young adults, but the consequences are much larger than that. Troubles can spread across households and to parents, who are often expected to help their children and provide support in times of need. Parents generally give more support to their children than they receive, even in old age (Choi, 2003; Ward et al., 1992). Many also provide housing support to their children regardless of their relationship quality (Ward \& Spitze, 2007), which is indicative of the strong norms surrounding expectations about parental support (Goldscheider et al., 2001; Yelowitz, 2007). However, extending support through housing and other means can also exhaust parental resources and limit savings, which shows that the intergenerational transmission of inequality does not just stem from parents to children. When adult children experience economic insecurity, this can also influence the economic wellbeing of their parents.

It is important to note that the financial transfers associated with coresidence might not result in a permanent drain on family resources. An alternative perspective could view the lost assets as an investment into the child's success. For instance, Sandberg-Thoma, Snyder, and Jang (2015) found that children with higher levels of education took longer to leave their parental homes, but they were less likely to return after moving out. In this situation, extended 
coresidence helped to provide youth with additional resources to improve their financial situations, which could create benefits for parents later on. Any later reciprocity, however, depends on the children's abilities to improve their own situations. Overall, the long-term consequences for parents who continue to support their adult children remain unknown and will likely be an interesting topic for further investigation.

These results demonstrate a need for future studies on the pathways of intergenerational inequality, how they relate to changing life course transitions, and how this influences stability among parents. Studies of social mobility have primarily focused on the pathways from parents to children, with less research on how financial hardship among children can affect parents. This presents an important pathway that will likely become more relevant over time. Although baby boomers have accumulated more wealth than their parents (Keister \& Deeb-Sossa, 2001), millennials will likely acquire less wealth than their baby boomer parents (Houle, 2014), and this study shows that their financial hardship can also influence the assets of parents.

On a policy level, my findings also indicate a need to consider broader household relationships when making decisions regarding social safety nets. This means acknowledging that parents are now supporting their children well into adulthood and adjusting policy to match. Recent healthcare policy revisions that allow children to remain on their parents' insurance plan until age 26 (Jacobs \& Skocpol, 2015) include this consideration, but there is more that can be done. Focusing on families and households, not just individuals, would also help to improve the situations of individuals in other types of extended household situations where they may be caring for and supporting different relatives. 


\section{References}

Addo, F.R. (2014). Debt, cohabitation, and marriage in young adulthood. Demography, 51(5), 1677-1701. doi:10.1007/s13524-014-0333-6

Albertini, M., \& Kohli, M. (2012). The generational contract in the family: An analysis of transfer regimes in Europe. European Sociological Review, 29(4), 828-840. doi:10.1093/esr/jcs061

Allison, P.D. (2009). Fixed effects regression models. California: Sage.

Aquilino, W.S. (1996). The returning adult child and parental experience at midlife. In C.D. Ryff and M. Seltzer (Eds.), The parental experience at midlife (pp. 423-458). Chicago: University of Chicago Press

Aquilino, W.S. (1990). The likelihood of parent-adult child coresidence: Effects of family structure and parental characteristics. Journal of Marriage and Family, 52(2), 405-419. http://www.jstor.org/stable/353035

Bianchi, S. M., Hotz, V. J., McGarry, K., \& Seltzer, J. A. (2007). Intergenerational ties: Alternative theories, empirical findings and trends, and remaining challenges (Report No. CCPR-024-06). Retrieved from California Center for Population Research On-Line Working Paper Series http://escholarship.org/uc/item/1g93v4kk.

Blau, P., \& Duncan, O.D. (1967). The American occupational structure. New York: The Free Press.

Bleemer, Z., Brown, M., Lee, D., \& van der Klaauw, W. 2014. Debt, jobs, or housing: What's keeping millennials at home? (Report No. 700). Washington, DC: Federal Reserve Bank of New York Staff Reports.

Bozick, R. \& Estacion, A. (2014). Do student loans delay marriage? Debt repayment and family 
formation in young adulthood. Demographic Research, 30, 1865-1891.

doi:10.4054/DemRes.2014.30.69

Bricker, J., Dettling, L.J., Henriques, A., Hsu, J.W., Moore, K.B., Sabelhaus, J., Thompson, J. \& Windle, R.A. (2014). Changes in U.S. family finances from 2010 to 2013: Evidence from the Survey of Consumer Finances. Federal Reserve Bulletin, 100(4), 1-41.

Cancian, M., \& Haskins, R. (2014). Changes in family composition: Implications for income, poverty, and public policy. The ANNALS of the American Academy of Political and Social Science, 654(1), 31-47. doi:10.1177/0002716214525322

Cherlin, A.J. (2010). Demographic trends in the United States: A review of research in the 2000s. Journal of Marriage and Family, 72(3), 403-419. doi: 10.1111/j.1741-3737.2010.00710.x

Choi, N.G. (2003). Coresidence between unmarried aging parents and their adult children: Who moved in with whom and why? Research on Aging, 25(4), 384-404. doi:10.1177/0164027503025004003

Cohen, P.N., \& Casper, L.M. (2002). In whose home? Multigenerational families in the United States, 1998-2000. Sociological Perspectives, 45(1), 1-20. doi:10.1525/sop.2002.45.1.1

Dettling, L.J. \& Hsu, J.W. (2014). Returning to the nest: Debt and parental co-residence among young adults (Report No. 2014-80). Washington, DC: Federal Reserve Board Finance and Economics Discussion Series.

Dey, J.G. \& Pierret, C.R. (2014). Independence for young millennials: Moving out and boomeranging back. Washington, DC: U.S. Bureau of Labor Statistics, Monthly Labor Review.

Dwyer, R.E., McCloud, L., \& Hodson, R. (2011). Youth debt, mastery, and self-esteem: Classstratified effects of indebtedness on self-concept. Social Science Research, 40(3), 727-41. 
doi:10.1016/j.ssresearch.2011.02.001

Elder, G.H., Jr. (1992). Models of the life course. Contemporary Sociology, 21(5), 632-635. http://www.jstor.org/stable/2075543

Elder, G.H., Jr. (1985). Life course dynamics: Trajectories and transitions, 1968-1980. Ithaca, NY: Cornell University Press.

Elliott, D.B., Young, R., \& Dye, J.L. (2011). Variation in the formation of complex family households during the recession (SEHSD Working Paper No. 2011-32). Washington, DC: U.S. Census Bureau.

Erikson, R., \& Goldthorpe, J. H. (2002). Intergenerational inequality: A sociological perspective. The Journal of Economic Perspectives, 16(3), 31-44. doi:10.1257/089533002760278695

Erikson, R. \& Goldthorpe, J.H. (1992). The constant flux: A study of class mobility in industrial societies. Oxford: Clarendon Press.

Fingerman, K., Kim, K., Davis, E., Furstenberg, F., Birditt, K., \& Zarit, S. (2015). "I'll give you the world": Socioeconomic differences in parental support of adult children. Journal of Marriage and Family, 77(4), 844-865. doi:10.1111/jomf.12204

Fingerman, K., Miller, L., Birditt, K., \& Zarit, S. (2009). Giving to the good and the needy: Parental support of grown children. Journal of Marriage and Family, 71(5), 1220-1233. doi:10.1111/j.1741-3737.2009.00665.x

Folbre, N. (2012). For love and money: Care provision in the United States. New York: Russell Sage.

Fry, R., \& Passel, J. S. (2014). In post-recession era, young adults drive continuing rise in multigenerational living. Washington, D.C.: Pew Research Center’s Social and Demographic Trends project, July. 
Furstenberg, F.F. (2010). On a new schedule: Transitions to adulthood and family change. Future of Children, 20(1), 67-87. doi:10.1353/foc.0.0038

Gelman, A., \& Hill, J. (2007). Data Analysis Using Regression and Multilevel/Hierarchical Models. New York: Cambridge University Press.

Glick, J.E. \& Van Hook, J. (2011). Does a house divided stand? Kinship and continuity of shared living arrangements. Journal of Marriage and Family, 73(5), 1149-1164. doi:10.1111/j.1741-3737.2011.00869.x

Glick, J.E. \& Van Hook, J. (2002). Parents' coresidence with adult children: Can immigration explain racial and ethnic variation? Journal of Marriage and Family, 64(1), 240-253. http://www.jstor.org/stable/3599791

Goldscheider, F. \& Goldscheider, C. (1999a). The changing transition to adulthood: Leaving and returning home. California: Sage.

Goldscheider, F. \& Goldscheider, C. (1999b). Changes in returning home in the US, 1925-1985. Social Forces, 78(2), 695-720. doi:10.1093/sf/78.2.695

Goldscheider, F.K., Thornton, A., \& and Yang, L. (2001). Helping out the kids: Expectations about parental support in young adulthood. Journal of Marriage and Family, 63(3), 727740. doi:10.1111/j.1741-3737.2001.00727.x

Grinstein-Weiss, M., Yeo, Y.H., Zhan, M., \& Charles, P. (2008). Asset holding and net worth among households with children: Differences by household type. Children and Youth Services Review, 30(1), 62-78. doi:10.1016/j.childyouth.2007.06.005

Hacker, J.S. (2006). The great risk shift: The new economic insecurity and the decline of the American dream. New York: Oxford University Press.

Hardie, J.H., \& Seltzer, J.A. (2016). Parent-child relationships and the transition to adulthood: A 
comparison of black, Hispanic, and white immigrant and native-born youth. Social Forces, 95(1), 321-353. doi:10.1093/sf/sow033

Houle, J.N. (2014). A generation indebted: Young adult debt across three cohorts. Social Problems, 61(3), 448-465. doi:10.1525/sp.2014.12110

Jacobs, L. and Skocpol, T., 2015. Health care reform and American politics: What everyone needs to know, Third edition. New York: Oxford University Press.

Kalmijn, M. (2013). The educational gradient in marriage: A comparison of 25 European countries. Demography, 50(4), 1499-1520. doi:10.1007/s13524-013-0229-х

Kamo, Y. (2000). Racial and ethnic differences in extended family households. Sociological Perspectives, 43(2), 211-229. doi:10.2307/1389794

Kaplan, G. (2012). Moving back home: Insurance against labor market risk. Journal of Political Economy, 120(3), 446-512. http://www.jstor.org/stable/10.1086/666588

Keister, L.A. (2000). Wealth in America: Trends in wealth inequality. New York: Cambridge University Press.

Keister, L.A., \& Deeb-Sossa, N. (2001). Are baby boomers richer than their parents? Intergenerational patterns of wealth ownership in the United States. Journal of Marriage and Family, 63(2), 569-579. doi:10.1111/j.1741-3737.2001.00569.x

Keister, L.A., \& Moller, S. (2000). Wealth inequality in the United States. Annual Review of Sociology, 26, 63-81. http://www.jstor.org/stable/223437

Kornrich, S., \& Furstenberg, F. (2013). Investing in children: Changes in parental spending on children, 1972-2007. Demography, 50(1), 1-23. doi:10.1007/s13524-012-0146-4

Lee, K.O., \& Painter, G. (2013). What happens to household formation in a recession? Journal of Urban Economics, 76, 93-109. doi:10.1016/j.jue.2013.03.004 
Lovenheim, M.F. (2011). The effect of liquid housing wealth on college enrollment. Journal of Labor Economics, 29(4), 741-771. http://www.jstor.org /stable/10.1086/660775

Lupton, J.P. \& Smith, J.P. (2003). Marriage, assets, and savings. In S.A. Grossbard-Shechtman (Ed.), Marriage and the economy: Theory and evidence from advanced industrial societies (pp. 129-152). New York: Cambridge University Press.

Macmillan, R., \& Copher, R. (2005). Families in the life course: Interdependency of roles, role configurations, and pathways. Journal of Marriage and Family, 67(4), 858-879. doi:10.1111/j.1741-3737.2005.00180.x

Mare, R.D. (2011). A multigenerational view of inequality. Demography, 48(1), 1-23. doi:10.1007/s13524-011-0014-7

McCall, L., \& Percheski, C. (2010). Income inequality: New trends and research directions. Annual Review of Sociology, 36, 329-347. doi:10.1146/annurev.soc.012809.102541

McCloud, L., \& Dwyer, R. E. (2011). The fragile American: Hardship and financial troubles in the 21st century. The Sociological Quarterly, 52(1), 13-35. doi:10.1111/j.15338525.2010.01197.x

Mykyta, L., \& Macartney, S. (2011). The effects of recession on household composition: "Doubling up" and economic well-being (SEHSD Working Paper No. 2011-4). Washington, DC: U.S. Census Bureau.

Nau, M., Dwyer, R.E., \& Hodson, R. (2015). Can't afford a baby? Debt and young Americans. Research in Social Stratification and Mobility, 42, 114-122. doi:10.1016/j.rssm.2015.05.003

Pfeffer, F. T. (2014). Multigenerational approaches to social mobility. A multifaceted research agenda. Research in Social Stratification and Mobility, 35, 1-12. 
doi:10.1016/j.rssm.2014.01.001

Pilkauskas, N.V., Garfinkel, I., \& McLanahan, S.S. (2014). The prevalence and economic value of doubling up. Demography, 51(5), 1667-1676. doi:10.1007/s13524-014-0327-4

Rauscher, E. 2016. Passing it on: Parent-to-adult child financial transfers for school and socioeconomic attainment. RSF Journal, 2(6), 172-196. doi:10.7758/RSF.2016.2.6.09

Sandberg-Thoma, S.E., Snyder, A.R., \& Jany, B.J. (2015). Exiting and returning to the parental home for boomerang kids. Journal of Marriage and Family, 77(3), 806-818. doi:10.1111/jomf.12183

Schoeni, R. F., \& Ross, K. E. (2005). Material assistance from families during the transition to adulthood. In R.A. Settersten, Jr., F.F. Furstenberg, Jr., \& R.G. Rumbaut (Eds.), On the frontier of adulthood (pp. 396-416). Chicago: University of Chicago Press.

Settersten, R.A. Jr., \& Ray, B. (2010). What's going on with young people today? The long and twisting path to adulthood. Future of Children, 20(1), 19-41. doi:10.1353/foc.0.0044

Seltzer, J.A., \& Bianchi, S.M. (2013). Demographic change and parent-child relationships in adulthood. Annual Review of Sociology, 39, 275-290. doi:10.1146/annurev-soc-071312145602

Seltzer, J., Lau, C. Q., \& Bianchi, S. (2012). Doubling up when times are tough: A study of obligations to share a home in response to economic hardship. Social Science Research, 4l(5), 1307-1319. doi:10.1016/j.ssresearch.2012.05.008

Semyonov, M., \& Lewin-Epstein, N. (2013). Ways to richness: Determination of household wealth in 16 countries. European Sociological Review, 29(6), 1134-1148. doi:10.1093/esr/jct001

Sironi, M., \& Furstenberg, F.F. (2012). Trends in the economic independence of young adults in 
the United States: 1973-2007. Population and Development Review, 38(4), 609-630. http://www.jstor.org /stable/41811931

Smits, A., van Gaalen, R.I., \& Mulder, C.H. (2010). Parent-child coresidence: Who moves in with whom and for whose needs? Journal of Marriage and Family, 72(4), 1022- 1033. doi:10.1111/j.1741-3737.2010.00746.x

Spilerman, S. (2000). Wealth and stratification processes. Annual Review of Sociology, 26, $497-$ 524. http://www.jstor.org/stable/223454

Steele, F., Clarke, P., \& Washbrook, E. (2013). Modeling household decisions using longitudinal data from household panel surveys, with applications to residential mobility. Sociological Methodology, 43(1), 220-271. doi:10.1177/0081175013479352

Swartz, T.T. (2009). Intergenerational family relations in adulthood: Patterns, variations and implications in the contemporary United States. Annual Review of Sociology, 35, 191212. doi:10.1146/annurev.soc.34.040507.134615

Swartz, T.T. (2008). Family capital and the invisible transfer of privilege: Intergenerational support and social class in early adulthood. New Directions for Child and Adolescent Development, 119, 11-24. doi:10.1002/cd.206

Swartz, T.T., Kim, M., Uno, M., Mortimer, J., \& Bengtson O'Brien, K. (2011). Safety nets and scaffolds: Parental support in the transition to adulthood. Journal of Marriage and Family, 73(2), 414-429. doi:10.1111/j.1741-3737.2010.00815.x

Taylor, P. (2014). The next America: Boomers, millennials, and the looming generational showdown. New York: Public Affairs.

U.S. Census Bureau. (2015). Families and living arrangements, Table AD-1. Young adults, 1834 years old, living at home: 1960 to present. Retrieved from 
http://www.census.gov/hhes/families/data/adults.html.

Ward, R.A., \& D. Spitze, G.D. (2007). Nestleaving and coresidence by young adult children: The role of family relations. Research on Aging, 29(3), 257-277. doi:10.1177/0164027506298225

Ward, R., Logan, J., \& Spitze, G. (1992). The influence of parent and child needs on coresidence in middle and later life. Journal of Marriage and the Family, 54(1), 209-221. http://www.jstor.org/stable/353288

Western, B., Bloome, D., Sosnaud, B., \& Tach, L. (2012). Economic insecurity and social stratification. Annual Review of Sociology, 38, 341-359. doi:10.1146/annurev-soc071811-145434

Wiemers, E.E. (2014). The effect of unemployment on household composition and doubling up. Demography, 51(6), 2155-2178. doi:10.1007/s13524-014-0347-0

Wolff, E. N. (2002). Inheritance and wealth inequality, 1989-1998. American Economic Review, 92(2), 260-264. doi:10.1257/000282802320189366

Yamokoski, A., \& Keister, L.A. (2006). The wealth of single women: Marital status and parenthood in the asset accumulation of young baby boomers in the United States. Feminist Economics, 12(1-2), 167-194. doi:10.1080/13545700500508478

Yelowitz A. (2007). Young adults leaving the nest: The role of the cost of living. In S. Danziger \& C.E. Rouse (Eds.), The price of independence: The economics of early adulthood, (pp. 170-207). New York: Russell Sage.

Zagorsky, J.L. (2005). Marriage and divorce's impact on wealth. Journal of Sociology, 41(4), 406-424. doi:10.1177/1440783305058478 
Table 1. Descriptive Statistics of NLSY79 Variables by Presence of Adult Children ${ }^{1}$

\begin{tabular}{|c|c|c|c|c|c|c|}
\hline & \multicolumn{2}{|l|}{ Total } & \multicolumn{2}{|c|}{$\begin{array}{l}\text { No Adult Children } \\
\text { Present } \\
\end{array}$} & \multicolumn{2}{|c|}{ Adult Children Present } \\
\hline & Estimate & SE & Estimate & SE & Estimate & SE \\
\hline $\mathrm{N}$ person-years & \multicolumn{2}{|c|}{16,108} & \multicolumn{2}{|c|}{9,679} & \multicolumn{2}{|c|}{6,429} \\
\hline Any financial assets ${ }^{2}$ & 79.09 & 0.36 & 77.45 & 0.48 & 81.60 & 0.54 \\
\hline Mean & $74,691.26$ & $2,435.98$ & $74,105.15$ & $3,304.61$ & $75,583.26$ & $3,528.00$ \\
\hline Median & $7,778.00$ & 352.56 & $6,684.86$ & 374.37 & $9,966.00$ & 610.92 \\
\hline Any savings ${ }^{2}$ & 72.70 & 0.41 & 71.26 & 0.54 & 74.89 & 0.62 \\
\hline Mean & $15,219.70$ & 609.27 & $15,548.47$ & 854.96 & $14,719.34$ & 817.22 \\
\hline Median & $1,667.03$ & 102.72 & $1,430.00$ & 77.55 & $2,000.00$ & 79.34 \\
\hline Adult child age $18+$ present, not usually at school & 39.65 & 0.47 & - & - & - & - \\
\hline $\begin{array}{l}\text { Adult child age } 18+\text { not present or usually at } \\
\text { school }\end{array}$ & 60.35 & 0.47 & - & - & - & - \\
\hline Not present but usually resides at home & 14.42 & 0.34 & - & - & - & - \\
\hline Not present and does not usually reside at home & 39.48 & 0.47 & - & - & - & - \\
\hline Usually resides at school & 6.45 & 0.25 & - & - & - & - \\
\hline \multicolumn{7}{|l|}{ Current marital status } \\
\hline Married & 63.99 & 0.45 & 58.94 & 0.60 & 71.68 & 0.65 \\
\hline Never married & 7.41 & 0.20 & 8.10 & 0.27 & 6.36 & 0.27 \\
\hline Formerly married & 28.60 & 0.43 & 32.96 & 0.58 & 21.95 & 0.61 \\
\hline Mean number of adults present & 2.36 & 0.89 & 1.87 & 0.85 & 3.11 & 1.09 \\
\hline Mean number of children present & 1.36 & 1.18 & 94.35 & 1.45 & 1.99 & 1.59 \\
\hline Mean total household income ${ }^{2}$ & $68,529.90$ & 660.62 & $65,160.17$ & 858.88 & $73,658.22$ & $1,027.37$ \\
\hline Mean weeks worked & 40.95 & 18.32 & 40.00 & 24.34 & 42.39 & 27.45 \\
\hline \multicolumn{7}{|l|}{ Employment status } \\
\hline Employed full-time & 69.46 & 0.44 & 68.06 & 0.58 & 71.59 & 0.69 \\
\hline Employed part-time & 11.29 & 0.31 & 10.97 & 0.40 & 11.79 & 0.51 \\
\hline Not employed & 19.25 & 0.37 & 20.97 & 0.49 & 16.62 & 0.55 \\
\hline \multicolumn{7}{|l|}{ Job gaps since age 20} \\
\hline No job gaps & 37.07 & 0.48 & 36.32 & 0.61 & 38.21 & 0.76 \\
\hline Single job gap & 23.20 & 0.42 & 23.12 & 0.53 & 23.31 & 0.66 \\
\hline Two+ job gaps & 39.74 & 0.47 & 40.56 & 0.60 & 38.48 & 0.73 \\
\hline Mean years of schooling completed (years) & 12.85 & 2.15 & 12.83 & 2.80 & 12.88 & 3.34 \\
\hline Currently enrolled in school & 2.83 & 0.15 & 2.70 & 0.19 & 3.02 & 0.25 \\
\hline Mean age (years) & 45.23 & 5.32 & 45.22 & 7.02 & 45.25 & 8.13 \\
\hline Health limitation & 13.23 & 0.32 & 13.98 & 0.42 & 12.11 & 0.49 \\
\hline Rural & 31.97 & 0.47 & 33.10 & 0.60 & 30.24 & 0.73 \\
\hline Female & 61.28 & 0.48 & 57.71 & 0.62 & 66.71 & 0.74 \\
\hline Non-Hispanic white & 73.53 & 0.33 & 74.22 & 0.42 & 72.49 & 0.54 \\
\hline Non-Hispanic black ${ }^{3}$ & 18.83 & 0.28 & 18.79 & 0.36 & 18.89 & 0.44 \\
\hline Hispanic origin $^{3}$ & 7.64 & 0.15 & 7.00 & 0.19 & 8.62 & 0.26 \\
\hline
\end{tabular}

SOURCE: NLSY 1979 Cohort 1994-2012, full sample, restricted to parents of adult children living in own dwellings. $\mathrm{N}=\mathrm{N}=16,108$ cases and $\mathrm{N}=4,761$ individuals, weighted using NLSY sample survey weights

NOTES: ${ }^{1}$ Estimates refer to percentages, unless otherwise noted. ${ }^{2}$ Earnings and assets in 2012 dollars. ${ }^{3}$ Due to oversampling in the NLSY, percentages of black and Hispanic respondents are larger than in the population. 
Table 2. Results of HME Models Predicting Any Financial Assets and Logged Financial Assets by Presence of Adult Children in the Household

\begin{tabular}{|c|c|c|c|c|c|c|}
\hline & \multicolumn{3}{|c|}{ Model 1 - Any Assets } & \multicolumn{3}{|c|}{ Model 2 - Logged Assets } \\
\hline & AME & $\mathrm{b}$ & SE & $\mathrm{e}^{\mathrm{b}}-1$ & $\mathrm{~b}$ & SE \\
\hline Intercept & & 1.377 & $(0.234)$ & 328.131 & $5.796 * * *$ & $(0.241)$ \\
\hline \multicolumn{7}{|l|}{ Time-varying Predictors } \\
\hline \multirow{2}{*}{\multicolumn{7}{|c|}{ Within-person Coefficients }} \\
\hline & & & & & & \\
\hline Adult child present, not usually at school & -0.022 & -0.210 & $(0.107)$ & -0.242 & $-0.277 * *$ & $(0.098)$ \\
\hline Adult child not present but usually resides at home & 0.001 & 0.011 & $(0.107)$ & -0.015 & -0.015 & $(0.096)$ \\
\hline Adult child usually resides at school & 0.002 & 0.021 & $(0.191)$ & -0.096 & -0.101 & $(0.142)$ \\
\hline Number of adults present & 0.003 & 0.032 & $(0.054)$ & 0.078 & 0.075 & $(0.050)$ \\
\hline Number of children present & 0.005 & 0.049 & $(0.046)$ & 0.015 & 0.015 & $(0.045)$ \\
\hline \multicolumn{7}{|l|}{ Marital status (Ref: Married) } \\
\hline Never married & -0.038 & -0.370 & $(0.282)$ & -0.419 & -0.543 & $(0.310)$ \\
\hline Formerly married & -0.037 & $-0.356 * *$ & $(0.114)$ & -0.456 & $-0.609 * * *$ & $(0.113)$ \\
\hline Age & 0.004 & $0.042 *$ & $(0.021)$ & 0.067 & $0.065^{* *}$ & $(0.022)$ \\
\hline Age squared & 0.000 & 0.002 & $(0.001)$ & 0.002 & 0.002 & $(0.001)$ \\
\hline Years of schooling completed & 0.004 & 0.035 & $(0.063)$ & 0.053 & 0.051 & $(0.065)$ \\
\hline Currently enrolled in school & -0.024 & -0.230 & $(0.181)$ & -0.145 & -0.157 & $(0.164)$ \\
\hline \multicolumn{7}{|l|}{ Job gaps since age 18 (Ref: No Gaps) } \\
\hline Single job gap & -0.014 & -0.139 & $(0.362)$ & -0.183 & -0.202 & $(0.361)$ \\
\hline Two+ job gaps & -0.067 & -0.639 & $(0.403)$ & -0.544 & -0.786 & $(0.409)$ \\
\hline \multicolumn{7}{|l|}{ Employment status (Ref: Employed full-time) } \\
\hline Employed part-time & -0.042 & $-0.406^{* * *}$ & $(0.113)$ & -0.273 & $-0.319 * *$ & $(0.108)$ \\
\hline Not employed & -0.068 & $-0.658 * * *$ & $(0.108)$ & -0.453 & $-0.603 * * *$ & $(0.107)$ \\
\hline Household wage and salary income & 0.007 & $0.071^{* * *}$ & $(0.013)$ & 0.117 & $0.110^{* * *}$ & $(0.013)$ \\
\hline Health limitation & 0.011 & 0.102 & $(0.106)$ & -0.099 & -0.104 & $(0.103)$ \\
\hline Rural & -0.014 & -0.136 & $(0.114)$ & -0.011 & -0.011 & $(0.104)$ \\
\hline Homeowner & 0.070 & $0.677 * * *$ & $(0.092)$ & 1.709 & $0.997 * * *$ & $(0.093)$ \\
\hline
\end{tabular}


Table 2. (cont.) Results of HME Models Predicting Any Financial Assets and Logged Financial Assets by Presence of Adult Children in the Household

\begin{tabular}{|c|c|c|c|c|c|c|}
\hline & \multicolumn{3}{|c|}{ Model 1 - Any Assets } & \multicolumn{3}{|c|}{ Model 2 - Logged Assets } \\
\hline & AME & $\mathrm{b}$ & SE & $\mathrm{e}^{\mathrm{b}}-1$ & $\mathrm{~b}$ & SE \\
\hline \multicolumn{7}{|l|}{ Between-person Coefficients } \\
\hline \multicolumn{7}{|l|}{ (Approximating Random Effects) } \\
\hline Adult child present, not usually at school & 0.036 & 0.349 & $(0.182)$ & 0.399 & 0.336 & $(0.190)$ \\
\hline Adult child not present but usually resides at home & 0.033 & 0.315 & $(0.238)$ & 0.406 & 0.340 & $(0.240)$ \\
\hline Adult child usually resides at school & 0.139 & $1.334 * * *$ & $(0.352)$ & 4.174 & $1.644 * * *$ & $(0.298)$ \\
\hline Number of adults present & -0.008 & -0.076 & $(0.085)$ & -0.021 & -0.021 & $(0.091)$ \\
\hline Number of children present & -0.018 & $-0.171 * * *$ & $(0.048)$ & -0.204 & $-0.228 * * *$ & $(0.050)$ \\
\hline \multicolumn{7}{|l|}{ Marital status (Ref: Married) } \\
\hline Never married & -0.065 & $-0.624 * * *$ & $(0.149)$ & -0.619 & $-0.964 * * *$ & $(0.168)$ \\
\hline Formerly married & -0.067 & $-0.643 * * *$ & $(0.128)$ & -0.622 & $-0.972 * * *$ & $(0.137)$ \\
\hline Age & 0.002 & 0.020 & $(0.021)$ & 0.039 & 0.038 & $(0.022)$ \\
\hline Age squared & 0.000 & 0.000 & $(0.003)$ & 0.001 & 0.001 & $(0.003)$ \\
\hline Years of schooling completed & 0.021 & $0.205^{* * *}$ & $(0.021)$ & 0.324 & $0.281 * * *$ & $(0.020)$ \\
\hline Currently enrolled in school & 0.000 & -0.004 & $(0.366)$ & -0.175 & -0.192 & $(0.364)$ \\
\hline \multicolumn{7}{|l|}{ Job gaps since age 18 (Ref: No Gaps) } \\
\hline Single job gap & -0.010 & -0.099 & $(0.127)$ & -0.214 & $-0.240 *$ & $(0.121)$ \\
\hline Two+ job gaps & -0.048 & $-0.464 * * *$ & $(0.109)$ & -0.556 & $-0.812 * * *$ & $(0.107)$ \\
\hline \multicolumn{7}{|l|}{ Employment status (Ref: Employed full-time) } \\
\hline Employed part-time & -0.042 & $-0.404 *$ & $(0.187)$ & -0.357 & $-0.442 * *$ & $(0.189)$ \\
\hline Not employed & -0.081 & $-0.782 * * *$ & $(0.181)$ & -0.363 & $-0.452 * *$ & $(0.192)$ \\
\hline Household wage and salary income & 0.024 & $0.234 * * *$ & $(0.021)$ & 0.393 & $0.331 * * *$ & $(0.022)$ \\
\hline Health limitation & 0.021 & 0.204 & $(0.168)$ & -0.310 & $-0.371 *$ & $(0.178)$ \\
\hline Rural & -0.051 & $-0.495 * * *$ & $(0.111)$ & -0.448 & $-0.595 * * *$ & $(0.111)$ \\
\hline Homeowner & 0.172 & $1.656^{* * *}$ & $(0.111)$ & 12.920 & $2.633 * * *$ & $(0.121)$ \\
\hline \multicolumn{7}{|l|}{ Time-invariant Predictors } \\
\hline Age at first child & 0.004 & $0.043 * * *$ & $(0.013)$ & 0.053 & $0.051 * * *$ & $(0.014)$ \\
\hline Female & 0.033 & $0.318 * * *$ & $(0.093)$ & 0.318 & $0.276^{* *}$ & $(0.094)$ \\
\hline Non-Hispanic black & -0.087 & $-0.840 * * *$ & $(0.097)$ & -0.534 & $-0.763 * * *$ & $(0.102)$ \\
\hline Hispanic origin & -0.061 & $-0.585 * * *$ & $(0.108)$ & -0.402 & $-0.513 * * *$ & $(0.111)$ \\
\hline Year & $\mathrm{X}$ & & & $\mathrm{X}$ & & \\
\hline \multicolumn{4}{|l|}{ Pseudo R-Squared } & \multicolumn{3}{|l|}{.423} \\
\hline Rho (ICC) & \multicolumn{3}{|l|}{.423} & \multicolumn{3}{|l|}{.353} \\
\hline $\mathrm{AIC}$ & \multicolumn{3}{|l|}{12944} & \multicolumn{3}{|l|}{84133} \\
\hline BIC & \multicolumn{3}{|l|}{13328} & \multicolumn{3}{|l|}{84533} \\
\hline \multicolumn{7}{|l|}{$* * * \mathrm{p}<.001, * * \mathrm{p}<.01, * \mathrm{p}<.05$} \\
\hline \multicolumn{7}{|c|}{$\begin{array}{l}\text { SOURCE: NLSY } 1979 \text { Cohort 1994-2012, full sample, restricted to parents of adult children living in own dwellings. } \mathrm{N}=16,108 \text { cases and } \mathrm{N}= \\
4,761 \text { individuals }\end{array}$} \\
\hline \multicolumn{7}{|c|}{$\begin{array}{l}\text { NOTES: Continuous variables (age, earnings, and grade) are grand mean centered. All models include covariates for the survey wave year. } \\
\text { Within-person coefficients approximate fixed effects. Between-person coefficients approximate random effects. Model } 1 \text { is a logit model } \\
\text { estimating whether the respondent reported any financial assets. "AME" refers to average marginal effects, which can be interpreted as a } \\
\text { percentage point change in the presence of assets associated with a unit change in the predictor variable. Model } 2 \text { is a linear model estimating } \\
\left.\text { logged financial assets. ( } \mathrm{e}^{\mathrm{b}}-1\right) \text { can be interpreted as a percent change in assets associated with a one-unit change in the predictor variable. }\end{array}$} \\
\hline
\end{tabular}


Table 3. Results of HME Models Predicting Any Financial Savings and Logged Savings by Presence of Adult Children in the Household

\begin{tabular}{|c|c|c|c|c|c|c|}
\hline & \multicolumn{3}{|c|}{ Model 1 - Any Savings } & \multicolumn{3}{|c|}{ Model 2 - Logged Savings } \\
\hline & AME & $\mathrm{b}$ & SE & $\mathrm{e}^{\mathrm{b}}-1$ & $\mathrm{~b}$ & SE \\
\hline Intercept & & $1.187 * * *$ & $(0.215)$ & & $5.161 * * *$ & $(0.224)$ \\
\hline \multicolumn{7}{|l|}{ Time-varying Predictors } \\
\hline \multicolumn{7}{|l|}{$\begin{array}{l}\text { Within-person Coefficients } \\
\text { (Approximating Fixed Effects) }\end{array}$} \\
\hline Adult child present, not usually at school & -0.025 & -0.192 & $(0.099)$ & -0.230 & $-0.261 * *$ & $(0.092)$ \\
\hline Adult child not present but usually resides at home & -0.005 & -0.035 & $(0.099)$ & -0.090 & -0.094 & $(0.090)$ \\
\hline Adult child usually resides at school & -0.007 & -0.055 & $(0.163)$ & -0.138 & -0.148 & $(0.133)$ \\
\hline Number of adults present & 0.000 & -0.004 & $(0.051)$ & 0.039 & 0.038 & $(0.047)$ \\
\hline Number of children present & 0.008 & 0.059 & $(0.043)$ & 0.019 & 0.019 & $(0.041)$ \\
\hline \multicolumn{7}{|l|}{ Marital status (Ref: Married) } \\
\hline Never married & -0.010 & -0.080 & $(0.271)$ & -0.199 & -0.222 & $(0.284)$ \\
\hline Formerly married & -0.045 & $-0.346 * * *$ & $(0.105)$ & -0.434 & $-0.570 * * *$ & $(0.105)$ \\
\hline Age & 0.004 & 0.029 & $(0.020)$ & 0.047 & $0.046^{*}$ & $(0.021)$ \\
\hline Age squared & 0.000 & 0.002 & $(0.001)$ & 0.002 & $0.002 *$ & $(0.001)$ \\
\hline Years of schooling completed & 0.011 & 0.088 & $(0.059)$ & 0.057 & 0.055 & $(0.060)$ \\
\hline Currently enrolled in school & -0.009 & -0.070 & $(0.163)$ & 0.017 & 0.017 & $(0.153)$ \\
\hline \multicolumn{7}{|l|}{ Job gaps since age 18 (Ref: No Gaps) } \\
\hline Single job gap & -0.025 & -0.191 & $(0.333)$ & -0.318 & -0.383 & $(0.333)$ \\
\hline Two+ job gaps & -0.066 & -0.505 & $(0.372)$ & -0.479 & -0.651 & $(0.376)$ \\
\hline \multicolumn{7}{|l|}{ Employment status (Ref: Employed full-time) } \\
\hline Employed part-time & -0.033 & $-0.253 * *$ & $(0.105)$ & -0.223 & $-0.253 *$ & $(0.100)$ \\
\hline Not employed & -0.069 & $-0.528 * * *$ & $(0.102)$ & -0.418 & $-0.542 * * *$ & $(0.100)$ \\
\hline Household wage and salary income & 0.008 & $0.058 * * *$ & $(0.012)$ & 0.076 & $0.073 * * *$ & $(0.012)$ \\
\hline Health limitation & 0.019 & 0.148 & $(0.101)$ & 0.057 & 0.055 & $(0.096)$ \\
\hline Rural & -0.015 & -0.115 & $(0.105)$ & -0.074 & -0.077 & $(0.097)$ \\
\hline Homeowner & 0.071 & $0.544 * * *$ & $(0.085)$ & 1.181 & $0.780 * * *$ & $(0.087)$ \\
\hline
\end{tabular}


Table 3. (cont.)

\section{Results of HME Models Predicting Any Financial Savings and Logged Savings by Presence of Adult Children in the Household}

\begin{tabular}{|c|c|c|c|c|c|c|}
\hline & \multicolumn{3}{|c|}{ Model 1 - Any Savings } & \multicolumn{3}{|c|}{ Model 2 - Logged Savings } \\
\hline & AME & $\mathrm{b}$ & SE & $\mathrm{e}^{\mathrm{b}}-1$ & $\mathrm{~b}$ & SE \\
\hline \multicolumn{7}{|l|}{ Between-person Coefficients } \\
\hline \multicolumn{7}{|l|}{ (Approximating Random Effects) } \\
\hline Adult child present, not usually at school & 0.016 & 0.124 & $(0.168)$ & 0.069 & 0.067 & $(0.177)$ \\
\hline Adult child not present but usually resides at home & 0.057 & 0.438 & $(0.218)$ & 0.545 & 0.435 & $(0.224)$ \\
\hline Adult child usually resides at school & 0.137 & $1.056^{* * *}$ & $(0.301)$ & 3.127 & $1.417 * * *$ & $(0.277)$ \\
\hline Number of adults present & -0.015 & -0.113 & $(0.080)$ & -0.098 & -0.104 & $(0.085)$ \\
\hline Number of children present & -0.018 & $-0.137 * *$ & $(0.045)$ & -0.159 & $-0.173 * * *$ & $(0.047)$ \\
\hline \multicolumn{7}{|l|}{ Marital status (Ref: Married) } \\
\hline Never married & -0.090 & $-0.690 * * *$ & $(0.141)$ & -0.609 & $-0.939 * * *$ & $(0.156)$ \\
\hline Formerly married & -0.092 & $-0.705 * * *$ & $(0.118)$ & -0.629 & $-0.991 * * *$ & $(0.128)$ \\
\hline Age & 0.003 & 0.024 & $(0.019)$ & 0.038 & 0.038 & $(0.020)$ \\
\hline Age squared & 0.000 & 0.002 & $(0.003)$ & 0.004 & 0.004 & $(0.003)$ \\
\hline Years of schooling completed & 0.024 & $0.182^{* * * *}$ & $(0.019)$ & 0.275 & $0.243 * * *$ & $(0.019)$ \\
\hline Currently enrolled in school & -0.014 & -0.106 & $(0.329)$ & -0.377 & -0.474 & $(0.340)$ \\
\hline \multicolumn{7}{|l|}{ Job gaps since age 18 (Ref: No Gaps) } \\
\hline Single job gap & -0.021 & -0.160 & $(0.112)$ & -0.232 & $-0.265^{*}$ & $(0.113)$ \\
\hline Two+ job gaps & -0.057 & $-0.439 * * *$ & $(0.098)$ & -0.518 & $-0.730 * * *$ & $(0.099)$ \\
\hline \multicolumn{7}{|l|}{ Employment status (Ref: Employed full-time) } \\
\hline Employed part-time & -0.026 & -0.199 & $(0.171)$ & -0.133 & -0.143 & $(0.176)$ \\
\hline Not employed & -0.080 & $-0.618 * * *$ & $(0.167)$ & -0.263 & -0.305 & $(0.179)$ \\
\hline Household wage and salary income & 0.028 & $0.213 * * *$ & $(0.020)$ & 0.300 & $0.263 * * *$ & $(0.021)$ \\
\hline Health limitation & -0.005 & -0.041 & $(0.156)$ & -0.433 & $-0.567 * * *$ & $(0.166)$ \\
\hline Rural & -0.056 & $-0.430 * * *$ & $(0.101)$ & -0.426 & $-0.554 * * *$ & $(0.103)$ \\
\hline Homeowner & 0.190 & $1.466 * * *$ & $(0.102)$ & 8.463 & $2.247 * * *$ & $(0.113)$ \\
\hline \multicolumn{7}{|l|}{ Time-invariant Predictors } \\
\hline Age at first child & 0.005 & $0.039 * *$ & $(0.012)$ & 0.052 & $0.051 * * *$ & $(0.013)$ \\
\hline Female & 0.029 & $0.225 * *$ & $(0.084)$ & 0.125 & 0.118 & $(0.087)$ \\
\hline Non-Hispanic black & -0.124 & $-0.952 * * *$ & $(0.089)$ & -0.646 & $-1.040 * * *$ & $(0.095)$ \\
\hline Hispanic origin & -0.074 & $-0.566^{* * *} *$ & $(0.098)$ & -0.435 & $-0.570 * * *$ & $(0.104)$ \\
\hline Year & $\mathrm{X}$ & & & $\mathrm{X}$ & & \\
\hline Pseudo R-Squared & & & & .376 & & \\
\hline Rho (ICC) & .404 & & & .357 & & \\
\hline AIC & 14971 & & & 81897 & & \\
\hline $\mathrm{BIC}$ & 15355 & & & 82297 & & \\
\hline \multicolumn{7}{|l|}{$* * * \mathrm{p}<.001, * * \mathrm{p}<.01, * \mathrm{p}<.05$} \\
\hline \multicolumn{7}{|c|}{$\begin{array}{l}\text { SOURCE: NLSY } 1979 \text { Cohort 1994-2012, full sample, restricted to parents of adult children living in own dwellings. } \mathrm{N}=16,108 \text { cases and } \mathrm{N}= \\
4,761 \text { individuals }\end{array}$} \\
\hline \multicolumn{7}{|c|}{$\begin{array}{l}\text { NOTES: Continuous variables (age, earnings, and grade) are grand mean centered. All models include covariates for the survey wave year. Within- } \\
\text { person coefficients approximate fixed effects. Between-person coefficients approximate random effects. Model } 1 \text { is a logit model estimating } \\
\text { whether the respondent reported any savings. "AME" refers to average marginal effects, which can be interpreted as a percentage point change in } \\
\left.\text { the presence of savings associated with a unit change in the predictor variable. Model } 2 \text { is a linear model estimating logged total savings. (e } \mathrm{e}^{\mathrm{b}}-1\right) \text { can } \\
\text { be interpreted as a percent change in assets associated with a one-unit change in the predictor variable. }\end{array}$} \\
\hline
\end{tabular}




\section{SUPPLEMENTAL REVIEWER APPENDIX}

I have included the attached Supplemental Appendix in order to further confirm the results presented in the full paper and to answer reviewer queries for additional analyses. In this appendix, I discuss (1.) my procedures for subsetting and restricting my final sample, (2.) additional descriptive statistics for key variables, and (3.) results from models that contained parents and non-parents within the sample.

This Appendix contains the following Tables and Figures:

Table A1. Sample Subsets for NLSY79 Data 1994-2012

Table A2. Unweighted Descriptive Statistics of NLSY79 Variables

Table A3. Results of HME Models Predicting Any Financial Assets and Logged Financial Assets by Presence of Adult Children in the Household, Parents and Non-parents Sample

Table A4. Results of HME Models Predicting Any Savings and Logged Total Savings by Presence of Adult Children in the Household, Parents and Non-parents Sample

Figure A1. Presence of Adult Children in the Household by Year, NLSY79 Data 1994-2012

Figure A2. Mean Financial Assets by Year, NLSY79 Data 1994-2012

Figure A3. Mean Savings by Year, NLSY79 Data 1994-2012 


\section{1. $\quad$ Sample Subsets}

In addition to a cross-sectional sample of 6,111 respondents, the NLSY79 originally included oversamples of 5,295 low-income, Hispanic, Latino, or black respondents and 1,280 respondents serving in the military. This provided a total sample of 12,686 individuals in 1979.

\section{[Table A1]}

As described by Table A1, I created the NLSY79 sample that I analyze in the paper in nine steps. First, I began with ten years of data from 1994-2012 for all 12,686 survey participants. I then removed non-interview cases for each of these years, which resulted in a sample of 17,621 person-years and 9,289 individuals. Most of the individuals lost at this step came from restrictions placed on the data by the survey. This resulted in the removal of most of the military oversample (1,079 individuals) because the survey stopped re-interviewing this group in 1985 and part of the low-income non-Hispanic non-black oversample (1,621 individuals) because the survey stopped re-interviewing this group in 1991.

I next restricted the sample to individuals who reported living in their own dwellings in order to better ensure that adult children were the "guests" and the parents were the "hosts" of each household. This reduced the sample to 72,425 person-years and 9,200 individuals. I then added an age restriction to better ensure that individuals were at least 15 years of age when they reported their first child, which reduced the sample to 67,643 person-years and 9,121 individuals.

The greatest restriction for my data occurred in my fifth step when I restricted the sample to parents with adult child age 18 and older. This led to a sample of 33,709 person-years and 6,645 individuals. I then removed additional years $(2002,2006$, and 2010$)$ where wealth data 
were not collected, other missing data, and outliers on the wealth data (asset variables > $\$ 2,000,000)$. Finally, I removed cases with only one observation present because at least two data points are necessary to assess within-person variation. This resulted in a final sample of 16,108 person-years and 4,761 individuals. I use this sample for analyses presented in the paper.

\section{2. $\quad$ Further Descriptive Statistics}

As a complement to the weighted descriptive statistics presented in Table 1 in the full paper, Table A2 presents unweighted descriptive statistics for the sample. Because the NLSY79 contains an oversample of low-income and racial minority households, the weighted estimates for assets, savings, and income in Table 1 are greater than the estimates for the unweighted estimates in Table A2. Weights also account for the different representation of racial minority groups in the sample, which is why unweighted descriptive statistics show a greater proportion of black and Hispanic parents in the sample than the weighted descriptives. Estimates for the percentages of adult children living inside and outside the household, however, are very similar across tables. Differences by other characteristics were also quite small when comparing results with and without sampling weights.

\section{[Table A2]}

In addition to this descriptive statistics table, I have also included three figures that depict trends in the percentage of children living at home (Figure A1), mean financial assets (Figure A2), and mean total savings (Figure A3) over time. These help to demonstrate how the variables 
might change across survey years. They also present estimates for individuals instead of personyears.

\section{[Figure A1]}

\section{[Figure A2]}

\section{[Figure A3]}

Figure A1 shows that the percentage of parents living with adult children remained stable over the years of the survey. Between 1994 and 2012, 35-40 percent of households had adult children present in them each year. As shown in Figure A2, on average, households experienced asset growth through the recession and saw declines in 2012. However, savings grew at a slow but steady rate throughout the time period under consideration, which is highlighted by the trends in Figure A3.

\section{Analyses for Parents and Non-Parents}

As a supplement to my analyses for parents with adult children age 18 and older (Tables 2-3 in full paper), I also present analyses for a broader sample that includes parents and nonparents. This sample is much larger and includes 37,898 observations and 8,099 individuals. Table A3 presents the results from HME models predicting any financial assets (Model 1) and logged total financial assets (Model 2) in relation to the presence of adult children inside and outside the home. Table A4 presents the results from HME models predicting any savings (Model 1) and logged total savings (Model 2) in relation to the presence of adult children inside and outside the home. The referent category across models is individuals (or person-years) without adult children. 


\section{[Table A3]}

\section{[Table A4]}

Beginning with the between-person results for financial assets in Table A3, on average, individuals with adult children present or not present in the household were 5 to 8 percentage points less likely to report any assets (Model 1) and held 59 to 73 percent less in total assets (Model 2) than individuals without adult children. Only individuals with adult children at school held more in assets than those without adult children.

In terms of the within-person differences, financial assets varied over time in relation to the presence of adult children within the household, as shown by the coefficients in the top panel of Table A3, but this was the only situation with significant negative effects over time. Compared to the years without adult children, younger baby boomers were no less likely to report any financial assets when adult children lived in the household, net of unobserved timeinvariant individual-level characteristics and time-varying covariates (Model 1). However, parents did hold less in financial assets when adult children were present in the household. Coresidence was associated with a decrease of 16.5 percent in financial assets (Model 2), but having adult children who usually lived in other situations did not lead to a specific decrease in assets during those years.

A similar situation was present for savings in Table A4. On average, individuals with adult children present or not present in the household were 6 to 10 percentage points less likely to report any savings (Model 1) and held 59 to 70 percent less in total savings (Model 2) than individuals without adult children. Individuals with adult children at school, however, held more in savings than those without adult children. 
Savings also varied over time in relation to the presence of adult children within the household, as shown by the within-person coefficients in the top panel of Table A4, but this was the only situation with significant negative effects over time. Compared to the years without adult children, younger baby boomers were no less likely to report any savings when adult children lived in the household (Model 1). However, parents did have less in savings when adult children were present in the household. Coresidence was associated with a decrease of 16 percent in savings (Model 2), but having adult children who usually lived in other situations did not lead to a specific decrease in savings during those years.

Thus, these findings replicate and expand the findings presented in the full paper. They show that, on average, individuals with adult children have less in assets and savings than those without. However, much of these declines in assets over time are associated with years where adult children were living in the household. 
Table A1. $\quad$ Sample Subsets for NLSY79 Data 1994-2012

\begin{tabular}{|c|c|c|c|}
\hline & $\begin{array}{l}\text { Person-years } \\
\text { (observations) }\end{array}$ & $\begin{array}{l}\text { Individuals } \\
\text { (cases) }\end{array}$ & Notes \\
\hline 1. Restrict to $1994-2012$ & 126,860 & 12,686 & $\begin{array}{l}\text { Beginning analyses with } 10 \text { years of data }(1994,1996,1998,2000, \\
2002,2004,2006,2008,2010,2012) \text { and full sample }\end{array}$ \\
\hline $\begin{array}{l}\text { 2. Remove non-interview cases } \\
\text { and parts of oversamples }\end{array}$ & 79,621 & 9,289 & $\begin{array}{l}\text { Removing non-interview cases for 1994-2012 also resulted in the } \\
\text { removal of most of the military oversample ( } 1079 \text { individuals) } \\
\text { because the survey stopped re-interviewing this group in } 1985 \text { and } \\
\text { part of the low-income non-Hispanic non-black oversample ( } 1621 \\
\text { individuals) because the survey stopped re-interviewing this group } \\
\text { in } 1991\end{array}$ \\
\hline 3. Restrict to own dwelling & 72,425 & 9,200 & $\begin{array}{l}\text { Restricting sample to individuals who live in their own dwellings in } \\
\text { order to better ensure that adult children are the guests and the } \\
\text { parents are the hosts }\end{array}$ \\
\hline 4. Restrict to age $33+$ & 67,643 & 9,121 & $\begin{array}{l}\text { Restricting sample to individuals age } 33 \text { and older in order to ensure } \\
\text { that individuals were at least } 15 \text { years of age when reporting first } \\
\text { child }\end{array}$ \\
\hline $\begin{array}{l}\text { 5. Restrict to parents with adult } \\
\text { children }\end{array}$ & 33,709 & 6,645 & Restricting sample to parents with adult children age $18+$ \\
\hline $\begin{array}{l}\text { 6. Remove years where wealth } \\
\text { data not asked }(2002,2006, \\
\text { and } 2010)\end{array}$ & 20,713 & 6,506 & $\begin{array}{l}\text { Removing years where wealth data were not collected }(2002,2006 \text {, } \\
\text { and 2010) }\end{array}$ \\
\hline 7. Remove other missing data & 17,555 & 6,185 & Removing missing data on all variables of interest \\
\hline $\begin{array}{l}\text { 8. Remove outliers on wealth } \\
\text { data }(>2,000,000)\end{array}$ & 17,522 & 6,175 & $\begin{array}{l}\text { Removing outliers on wealth data with savings or assets greater than } \\
\$ 2 \text { million dollars (2012 USD) }\end{array}$ \\
\hline $\begin{array}{l}\text { 9. Remove cases with only one } \\
\text { observation }\end{array}$ & 16,108 & 4,761 & $\begin{array}{l}\text { Removing cases with only one observation available because at least } \\
\text { two data points are necessary to assess within-person variation }\end{array}$ \\
\hline
\end{tabular}


Table A2. $\quad$ Unweighted Descriptive Statistics of NLSY79 Variables ${ }^{1}$

\begin{tabular}{|c|c|c|c|}
\hline & Total & $\begin{array}{c}\text { Adult Children } \\
\text { Not Present }\end{array}$ & $\begin{array}{l}\text { Adult Children } \\
\text { Present } \\
\end{array}$ \\
\hline $\mathrm{N}$ person-years & 16,108 & 9,679 & 6,429 \\
\hline Any financial assets ${ }^{2}$ & 71.95 & 70.48 & 74.16 \\
\hline Mean & $55,852.52$ & $54,605.89$ & $57,729.33$ \\
\hline Median & $3,337.00$ & $2,861.00$ & $4,267.00$ \\
\hline Any savings ${ }^{2}$ & 64.73 & 63.75 & 66.22 \\
\hline Mean & $10,727.67$ & $11,002.38$ & $10,314.08$ \\
\hline Median & 800.00 & 715.00 & $1,000.00$ \\
\hline Adult child age $18+$ present, not usually at school & 39.91 & - & - \\
\hline Adult child age $18+$ not present or usually at school & 60.09 & - & - \\
\hline Not present but usually resides at home & 14.07 & - & - \\
\hline Not present and does not usually reside at home & 40.84 & - & - \\
\hline Usually resides at school & 5.18 & - & - \\
\hline \multicolumn{4}{|l|}{ Current marital status } \\
\hline Married & 55.92 & 51.41 & 62.72 \\
\hline Never married & 12.28 & 12.94 & 11.29 \\
\hline Formerly married & 31.80 & 35.65 & 25.99 \\
\hline Mean number of adults present & 2.32 & 1.81 & 3.08 \\
\hline Mean number of children present & 1.40 & 0.96 & 2.06 \\
\hline Mean total household income ${ }^{2}$ & $57,946.23$ & $55,111.88$ & $62,213.39$ \\
\hline Mean weeks worked & 39.46 & 38.57 & 40.80 \\
\hline \multicolumn{4}{|l|}{ Employment status } \\
\hline Employed full-time & 67.76 & 66.58 & 69.54 \\
\hline Employed part-time & 10.16 & 9.86 & 10.61 \\
\hline Not employed & 22.08 & 23.57 & 19.85 \\
\hline \multicolumn{4}{|l|}{ Job gaps since age 18} \\
\hline No job gaps & 31.90 & 31.29 & 32.80 \\
\hline Single job gap & 22.01 & 22.01 & 22.01 \\
\hline Two+ job gaps & 46.10 & 46.70 & 45.19 \\
\hline Mean years of schooling completed (years) & 12.61 & 12.62 & 12.60 \\
\hline Currently enrolled in school & 3.14 & 2.94 & 3.44 \\
\hline Mean age (years) & 44.82 & 44.79 & 44.87 \\
\hline Health limitation & 14.21 & 14.99 & 13.03 \\
\hline Rural & 25.51 & 26.46 & 24.08 \\
\hline Female & 61.50 & 56.56 & 68.95 \\
\hline Non-Hispanic white & 44.45 & 45.73 & 42.53 \\
\hline Non-Hispanic black & 34.98 & 35.31 & 34.48 \\
\hline Hispanic origin & 20.57 & 18.96 & 22.99 \\
\hline
\end{tabular}

SOURCE: NLSY 1979 Cohort 1994-2012, full sample, restricted to parents of adult children living in own dwellings. $\mathrm{N}=16,108$ cases and $\mathrm{N}=4,761$ individuals unweighted

NOTES: ${ }^{1}$ Estimates refer to percentages, unless otherwise noted. ${ }^{2}$ Earnings, assets, and savings in 2012 dollars. 3 Due to oversampling in the NLSY, percentages of black and Hispanic respondents are larger than in the population. 
Table A3. $\quad$ Results of HME Models Predicting Any Financial Assets and Logged Financial Assets by Presence of Adult Children in the Household, Parents and Non-parents Sample

\begin{tabular}{|c|c|c|c|c|c|c|}
\hline & \multicolumn{3}{|c|}{ Model 1 - Any Assets } & \multicolumn{3}{|c|}{ Model 2 - Logged Assets } \\
\hline & AME & $\mathrm{b}$ & SE & $\mathrm{e}^{\mathrm{b}}-1$ & $\mathrm{~b}$ & SE \\
\hline Intercept & & $2.803 * * *$ & $(0.216)$ & & $7.212 * * *$ & $(0.203)$ \\
\hline \multicolumn{7}{|l|}{ Time-varying Predictors } \\
\hline \multicolumn{7}{|l|}{$\begin{array}{l}\text { Within-person Coefficients } \\
\text { (Approximating Fixed Effects) }\end{array}$} \\
\hline Adult child present, not usually at school & -0.013 & -0.152 & $(0.091)$ & -0.165 & $-0.181^{*}$ & $(0.074)$ \\
\hline Adult child not present but usually resides at home & -0.005 & -0.062 & $(0.077)$ & -0.069 & -0.071 & $(0.062)$ \\
\hline Adult child not present and does not usually reside at home & 0.002 & 0.028 & $(0.088)$ & 0.071 & 0.068 & $(0.075)$ \\
\hline Adult child usually resides at school & -0.004 & -0.045 & $(0.167)$ & -0.069 & -0.071 & $(0.111)$ \\
\hline Number of adults present & 0.001 & 0.017 & $(0.039)$ & 0.066 & 0.064 & $(0.034)$ \\
\hline Number of children present & 0.000 & -0.006 & $(0.029)$ & -0.032 & -0.033 & $(0.025)$ \\
\hline \multicolumn{7}{|l|}{ Marital status (Ref: Married) } \\
\hline Never married & -0.033 & $-0.396 * *$ & $(0.148)$ & -0.355 & $-0.439 * * *$ & $(0.130)$ \\
\hline Formerly married & -0.040 & $-0.475 * * *$ & $(0.077)$ & -0.522 & $-0.738 * * *$ & $(0.068)$ \\
\hline Age & 0.000 & 0.006 & $(0.015)$ & 0.047 & $0.046^{* * * *}$ & $(0.014)$ \\
\hline Age squared & 0.000 & 0.001 & $(0.001)$ & 0.001 & 0.001 & $(0.001)$ \\
\hline Years of schooling completed & -0.001 & -0.014 & $(0.046)$ & 0.018 & 0.018 & $(0.040)$ \\
\hline Currently enrolled in school & -0.015 & -0.175 & $(0.122)$ & -0.106 & -0.112 & $(0.091)$ \\
\hline \multicolumn{7}{|l|}{ Job gaps since age 18 (Ref: No Gaps) } \\
\hline Single job gap & -0.022 & -0.257 & $(0.213)$ & -0.236 & -0.269 & $(0.186)$ \\
\hline Two+ job gaps & -0.025 & -0.298 & $(0.243)$ & -0.373 & $-0.467 *$ & $(0.217)$ \\
\hline \multicolumn{7}{|l|}{ Employment status (Ref: Employed full-time) } \\
\hline Employed part-time & -0.029 & $-0.347 * * *$ & $(0.077)$ & -0.266 & $-0.309 * * *$ & $(0.062)$ \\
\hline Not employed & -0.051 & $-0.607 * * *$ & $(0.073)$ & -0.403 & $-0.515^{* * *}$ & $(0.063)$ \\
\hline Household wage and salary income & 0.007 & $0.084 * * *$ & $(0.009)$ & 0.120 & $0.113 * * *$ & $(0.008)$ \\
\hline Health limitation & 0.016 & $0.189 *$ & $(0.076)$ & -0.015 & -0.015 & $(0.066)$ \\
\hline Rural & 0.001 & 0.010 & $(0.071)$ & 0.074 & 0.071 & $(0.054)$ \\
\hline Homeowner & 0.050 & $0.594 * * *$ & $(0.060)$ & 1.146 & $0.763 * * *$ & $(0.053)$ \\
\hline
\end{tabular}


Table A3. (cont.) Results of HME Models Predicting Any Financial Assets and Logged Financial Assets by Presence of Adult Children in the Household, Parents and Non-parents Sample

\begin{tabular}{|c|c|c|c|c|c|c|}
\hline & \multicolumn{3}{|c|}{ Model 1 - Any Assets } & \multicolumn{3}{|c|}{ Model 2 - Logged Assets } \\
\hline & AME & $\mathrm{b}$ & SE & $\mathrm{e}^{\mathrm{b}}-1$ & $\mathrm{~b}$ & SE \\
\hline \multicolumn{7}{|l|}{$\begin{array}{l}\text { Between-person Coefficients } \\
\text { (Approximating Random Effects) }\end{array}$} \\
\hline Adult child present, not usually at school & -0.046 & $-0.539 * * *$ & $(0.166)$ & -0.588 & $-0.886^{* * *}$ & $(0.167)$ \\
\hline Adult child not present but usually resides at home & -0.051 & $-0.608 * * *$ & $(0.155)$ & -0.616 & $-0.956 * * *$ & $(0.161)$ \\
\hline Adult child not present and does not usually reside at home & -0.087 & $-1.031 * * *$ & $(0.129)$ & -0.726 & $-1.294 * * *$ & $(0.134)$ \\
\hline Adult child usually resides at school & 0.045 & 0.537 & $(0.415)$ & 2.060 & $1.118^{* *}$ & $(0.360)$ \\
\hline Number of adults present & -0.012 & $-0.136^{*}$ & $(0.065)$ & -0.076 & -0.079 & $(0.068)$ \\
\hline Number of children present & -0.011 & $-0.135 * * *$ & $(0.035)$ & -0.166 & $-0.182 * * *$ & $(0.035)$ \\
\hline \multicolumn{7}{|l|}{ Marital status (Ref: Married) } \\
\hline Never married & -0.058 & $-0.690 * * *$ & $(0.107)$ & -0.539 & $-0.774 * * *$ & $(0.109)$ \\
\hline Formerly married & -0.068 & $-0.801 * * *$ & $(0.104)$ & -0.611 & $-0.944 * * *$ & $(0.107)$ \\
\hline Age & 0.002 & 0.022 & $(0.016)$ & 0.060 & $0.059 * * *$ & $(0.015)$ \\
\hline Age squared & 0.000 & -0.004 & $(0.002)$ & -0.004 & -0.004 & $(0.002)$ \\
\hline Years of schooling completed & 0.022 & $0.263 * * *$ & $(0.015)$ & 0.380 & $0.322 * * *$ & $(0.013)$ \\
\hline Currently enrolled in school & 0.004 & 0.046 & $(0.283)$ & -0.300 & -0.357 & $(0.258)$ \\
\hline \multicolumn{7}{|l|}{ Job gaps since age 18 (Ref: No Gaps) } \\
\hline Single job gap & -0.005 & -0.064 & $(0.089)$ & -0.138 & -0.149 & $(0.080)$ \\
\hline Two+ job gaps & -0.043 & $-0.509 * * *$ & $(0.077)$ & -0.520 & $-0.734 * * *$ & $(0.071)$ \\
\hline \multicolumn{7}{|l|}{ Employment status (Ref: Employed full-time) } \\
\hline Employed part-time & -0.028 & $-0.326^{*}$ & $(0.149)$ & -0.296 & $-0.351 *$ & $(0.140)$ \\
\hline Not employed & -0.040 & $-0.478 * * *$ & $(0.143)$ & 0.143 & 0.133 & $(0.137)$ \\
\hline Household wage and salary income & 0.023 & $0.274 * * *$ & $(0.018)$ & 0.519 & $0.418^{* * *}$ & $(0.017)$ \\
\hline Health limitation & 0.019 & 0.219 & $(0.145)$ & -0.324 & $-0.392 * *$ & $(0.147)$ \\
\hline Rural & -0.055 & $-0.654 * * *$ & $(0.088)$ & -0.535 & $-0.767 * * *$ & $(0.083)$ \\
\hline Homeowner & 0.150 & $1.769 * * *$ & $(0.086)$ & 14.635 & $2.750 * * *$ & $(0.088)$ \\
\hline \multicolumn{7}{|l|}{ Time-invariant Predictors } \\
\hline Age at first child & 0.000 & -0.003 & $(0.003)$ & 0.001 & 0.001 & $(0.003)$ \\
\hline Female & 0.026 & $0.311^{* * *}$ & $(0.065)$ & 0.233 & $0.209 * * *$ & $(0.062)$ \\
\hline Non-Hispanic black & -0.088 & $-1.035 * * *$ & $(0.070)$ & -0.648 & $-1.045 * * *$ & $(0.070)$ \\
\hline Hispanic origin & -0.054 & $-0.638 * * *$ & $(0.078)$ & -0.447 & $-0.593 * * *$ & $(0.077)$ \\
\hline Year & $\mathrm{X}$ & & & $\mathrm{X}$ & & \\
\hline Pseudo R-Squared & & & & .458 & & \\
\hline Rho & .419 & & & .377 & & \\
\hline AIC & 25775 & & & 190854 & & \\
\hline BIC & 26219 & & & 191316 & & \\
\hline \multicolumn{7}{|l|}{$* * * \mathrm{p}<.001, * * \mathrm{p}<.01, * \mathrm{p}<.05$} \\
\hline \multicolumn{7}{|c|}{ SOURCE: NLSY 1979 Cohort 1994-2012, full sample, restricted to adults living in own dwellings. $\mathrm{N}=37,898$ cases and $\mathrm{N}=8,099$ individuals } \\
\hline \multicolumn{7}{|c|}{$\begin{array}{l}\text { NOTES: Continuous variables (age, earnings, and grade) are grand mean centered. All models include covariates for the survey wave year. Within- } \\
\text { person coefficients approximate fixed effects. Between-person coefficients approximate random effects. Model } 1 \text { is a logit model estimating } \\
\text { whether the respondent reported any financial assets. "AME" refers to average marginal effects, which can be interpreted as a percentage point } \\
\text { change in the presence of assets associated with a unit change in the predictor variable. Model } 2 \text { is a linear model estimating logged financial assets. } \\
\left(\mathrm{e}^{\mathrm{b}}-1\right) \text { can be interpreted as a percent change in assets associated with a one-unit change in the predictor variable. }\end{array}$} \\
\hline
\end{tabular}


Table A4. Results of HME Models Predicting Any Savings and Logged Total Savings by Presence of Adult Children in the Household, Parents and Non-parents Sample

\begin{tabular}{|c|c|c|c|c|c|c|}
\hline & \multicolumn{3}{|c|}{ Model 1 - Any Savings } & \multicolumn{3}{|c|}{ Model 2 - Logged Savings } \\
\hline & AME & $\mathrm{b}$ & SE & $\mathrm{e}^{\mathrm{b}}-1$ & $\mathrm{~b}$ & SE \\
\hline Intercept & & $2.570 * * *$ & $(0.198)$ & & $6.583 * * *$ & $(0.193)$ \\
\hline \multicolumn{7}{|l|}{ Time-varying Predictors } \\
\hline \multicolumn{7}{|l|}{$\begin{array}{l}\text { Within-person Coefficients } \\
\text { (Approximating Fixed Effects) }\end{array}$} \\
\hline Adult child present, not usually at school & -0.009 & -0.086 & $(0.082)$ & -0.160 & $-0.175 * *$ & $(0.071)$ \\
\hline Adult child not present but usually resides at home & 0.006 & 0.053 & $(0.071)$ & 0.001 & 0.001 & $(0.060)$ \\
\hline Adult child not present and does not usually reside at home & 0.006 & 0.059 & $(0.080)$ & 0.041 & 0.040 & $(0.071)$ \\
\hline Adult child usually resides at school & -0.008 & -0.073 & $(0.142)$ & -0.103 & -0.109 & $(0.107)$ \\
\hline Number of adults present & -0.001 & -0.012 & $(0.036)$ & 0.025 & 0.024 & $(0.032)$ \\
\hline Number of children present & -0.001 & -0.007 & $(0.027)$ & -0.025 & -0.025 & $(0.024)$ \\
\hline \multicolumn{7}{|l|}{ Marital status (Ref: Married) } \\
\hline Never married & -0.024 & -0.222 & $(0.138)$ & -0.253 & $-0.292 *$ & $(0.122)$ \\
\hline Formerly married & -0.052 & $-0.485^{* * * *}$ & $(0.070)$ & -0.506 & $-0.705^{* * *}$ & $(0.065)$ \\
\hline Age & -0.001 & -0.009 & $(0.014)$ & 0.029 & $0.028 *$ & $(0.013)$ \\
\hline Age squared & 0.000 & 0.001 & $(0.001)$ & 0.001 & 0.001 & $(0.001)$ \\
\hline Years of schooling completed & 0.003 & 0.027 & $(0.042)$ & 0.012 & 0.012 & $(0.037)$ \\
\hline Currently enrolled in school & -0.004 & -0.040 & $(0.108)$ & -0.014 & -0.014 & $(0.089)$ \\
\hline \multicolumn{7}{|l|}{ Job gaps since age 18 (Ref: No Gaps) } \\
\hline Single job gap & -0.031 & -0.292 & $(0.196)$ & -0.257 & -0.297 & $(0.175)$ \\
\hline Two+ job gaps & -0.032 & -0.299 & $(0.225)$ & -0.275 & -0.322 & $(0.204)$ \\
\hline \multicolumn{7}{|l|}{ Employment status (Ref: Employed full-time) } \\
\hline Employed part-time & -0.019 & $-0.180 *$ & $(0.071)$ & -0.150 & $-0.163 * *$ & $(0.060)$ \\
\hline Not employed & -0.053 & $-0.498 * * *$ & $(0.068)$ & -0.349 & $-0.429 * * *$ & $(0.061)$ \\
\hline Household wage and salary income & 0.008 & $0.073 * * *$ & $(0.009)$ & 0.100 & $0.095^{* * *}$ & $(0.008)$ \\
\hline Health limitation & 0.021 & $0.197 * *$ & $(0.072)$ & 0.058 & 0.056 & $(0.064)$ \\
\hline Rural & -0.002 & -0.016 & $(0.064)$ & 0.008 & 0.008 & $(0.052)$ \\
\hline Homeowner & 0.051 & $0.478 * * *$ & $(0.055)$ & 0.811 & $0.594 * * *$ & $(0.051)$ \\
\hline
\end{tabular}


Table A4. (cont.) Results of HME Models Predicting Any Savings and Logged Total Savings by Presence of Adult Children in the Household, Parents and Non-parents Sample

\begin{tabular}{|c|c|c|c|c|c|c|}
\hline & \multicolumn{3}{|c|}{ Model 1 - Any Savings } & \multicolumn{3}{|c|}{ Model 2 - Logged Savings } \\
\hline & AME & $\mathrm{b}$ & SE & $\mathrm{e}^{\mathrm{b}}-1$ & $\mathrm{~b}$ & SE \\
\hline \multicolumn{7}{|l|}{ Between-person Coefficients } \\
\hline \multicolumn{7}{|l|}{ (Approximating Random Effects) } \\
\hline Adult child present, not usually at school & -0.060 & $-0.564 * * *$ & $(0.155)$ & -0.590 & $-0.891 * * *$ & $(0.159)$ \\
\hline Adult child not present but usually resides at home & -0.069 & $-0.644 * * *$ & $(0.146)$ & -0.603 & $-0.924 * * *$ & $(0.153)$ \\
\hline Adult child not present and does not usually reside at home & -0.104 & $-0.971 * * *$ & $(0.122)$ & -0.701 & $-1.207 * * *$ & $(0.127)$ \\
\hline Adult child usually resides at school & 0.057 & 0.530 & $(0.369)$ & 1.707 & $0.996 * *$ & $(0.342)$ \\
\hline Number of adults present & -0.023 & $-0.213 * * *$ & $(0.062)$ & -0.170 & $-0.186 * *$ & $(0.065)$ \\
\hline Number of children present & -0.013 & $-0.120 * * *$ & $(0.033)$ & -0.157 & $-0.171 * * *$ & $(0.033)$ \\
\hline \multicolumn{7}{|l|}{ Marital status (Ref: Married) } \\
\hline Never married & -0.074 & $-0.689 * * *$ & $(0.100)$ & -0.523 & $-0.741 * * *$ & $(0.103)$ \\
\hline Formerly married & -0.086 & $-0.806 * * *$ & $(0.097)$ & -0.615 & $-0.953 * * *$ & $(0.101)$ \\
\hline Age & 0.002 & 0.022 & $(0.014)$ & 0.053 & $0.052 * * *$ & $(0.014)$ \\
\hline Age squared & 0.000 & -0.004 & $(0.002)$ & -0.004 & -0.004 & $(0.002)$ \\
\hline Years of schooling completed & 0.026 & $0.240 * * *$ & $(0.013)$ & 0.345 & $0.297 * * *$ & $(0.012)$ \\
\hline Currently enrolled in school & -0.042 & -0.394 & $(0.250)$ & -0.504 & $-0.702 * *$ & $(0.245)$ \\
\hline \multicolumn{7}{|l|}{ Job gaps since age 18 (Ref: No Gaps) } \\
\hline Single job gap & -0.014 & -0.129 & $(0.080)$ & -0.157 & $-0.171 *$ & $(0.076)$ \\
\hline Two+ job gaps & -0.050 & $-0.468 * * *$ & $(0.069)$ & -0.485 & $-0.664 * * *$ & $(0.067)$ \\
\hline \multicolumn{7}{|l|}{ Employment status (Ref: Employed full-time) } \\
\hline Employed part-time & -0.015 & -0.137 & $(0.136)$ & -0.095 & -0.100 & $(0.133)$ \\
\hline Not employed & -0.032 & $-0.301 *$ & $(0.131)$ & 0.233 & 0.210 & $(0.130)$ \\
\hline Household wage and salary income & 0.027 & $0.255^{* * *}$ & $(0.017)$ & 0.397 & $0.334 * * *$ & $(0.016)$ \\
\hline Health limitation & -0.006 & -0.053 & $(0.136)$ & -0.484 & $-0.662 * * *$ & $(0.140)$ \\
\hline Rural & -0.056 & $-0.520 * * *$ & $(0.080)$ & -0.494 & $-0.681 * * *$ & $(0.079)$ \\
\hline Homeowner & 0.168 & $1.569 * * *$ & $(0.079)$ & 9.898 & $2.389 * * *$ & $(0.083)$ \\
\hline \multicolumn{7}{|l|}{ Time-invariant Predictors } \\
\hline Age at first child & 0.000 & -0.003 & $(0.003)$ & -0.001 & -0.001 & $(0.003)$ \\
\hline Female & 0.021 & $0.201 * * *$ & $(0.059)$ & 0.077 & 0.074 & $(0.059)$ \\
\hline Non-Hispanic black & -0.111 & $-1.039 * * *$ & $(0.065)$ & -0.681 & $-1.143 * * *$ & $(0.067)$ \\
\hline Hispanic origin & -0.059 & $-0.552 * * *$ & $(0.071)$ & -0.420 & $-0.545 * * *$ & $(0.073)$ \\
\hline Year & $\mathrm{X}$ & & & $\mathrm{X}$ & & \\
\hline Pseudo R-Squared & & & & .408 & & \\
\hline Rho & .404 & & & .361 & & \\
\hline AIC & 30383 & & & 188408 & & \\
\hline BIC & 30827 & & & 188869 & & \\
\hline \multicolumn{7}{|l|}{$* * * \mathrm{p}<.001, * * \mathrm{p}<.01, * \mathrm{p}<.05$} \\
\hline \multicolumn{7}{|c|}{ SOURCE: NLSY 1979 Cohort 1994-2012, full sample, restricted to adults living in own dwellings. $\mathrm{N}=37,898$ cases and $\mathrm{N}=8,099$ individuals } \\
\hline \multicolumn{7}{|c|}{$\begin{array}{l}\text { NOTES: Continuous variables (age, earnings, and grade) are grand mean centered. All models include covariates for the survey wave year. Within } \\
\text { person coefficients approximate fixed effects. Between-person coefficients approximate random effects. Model } 1 \text { is a logit model estimating } \\
\text { whether the respondent reported any savings "AME" refers to average marginal effects, which can be interpreted as a percentage point change in } \\
\text { the presence of savings associated with a unit change in the predictor variable. Model } 2 \text { is a linear model estimating logged total savings. ( } \mathrm{e}^{\mathrm{b}}-1 \text { ) } \\
\text { can be interpreted as a percent change in assets associated with a one-unit change in the predictor variable. }\end{array}$} \\
\hline
\end{tabular}


Figure A1. Presence of Adult Children in the Household by Year, NLSY79 Data 1994-2012

\section{Percentage of Households with Adult Children Age 18+ Present by Year}

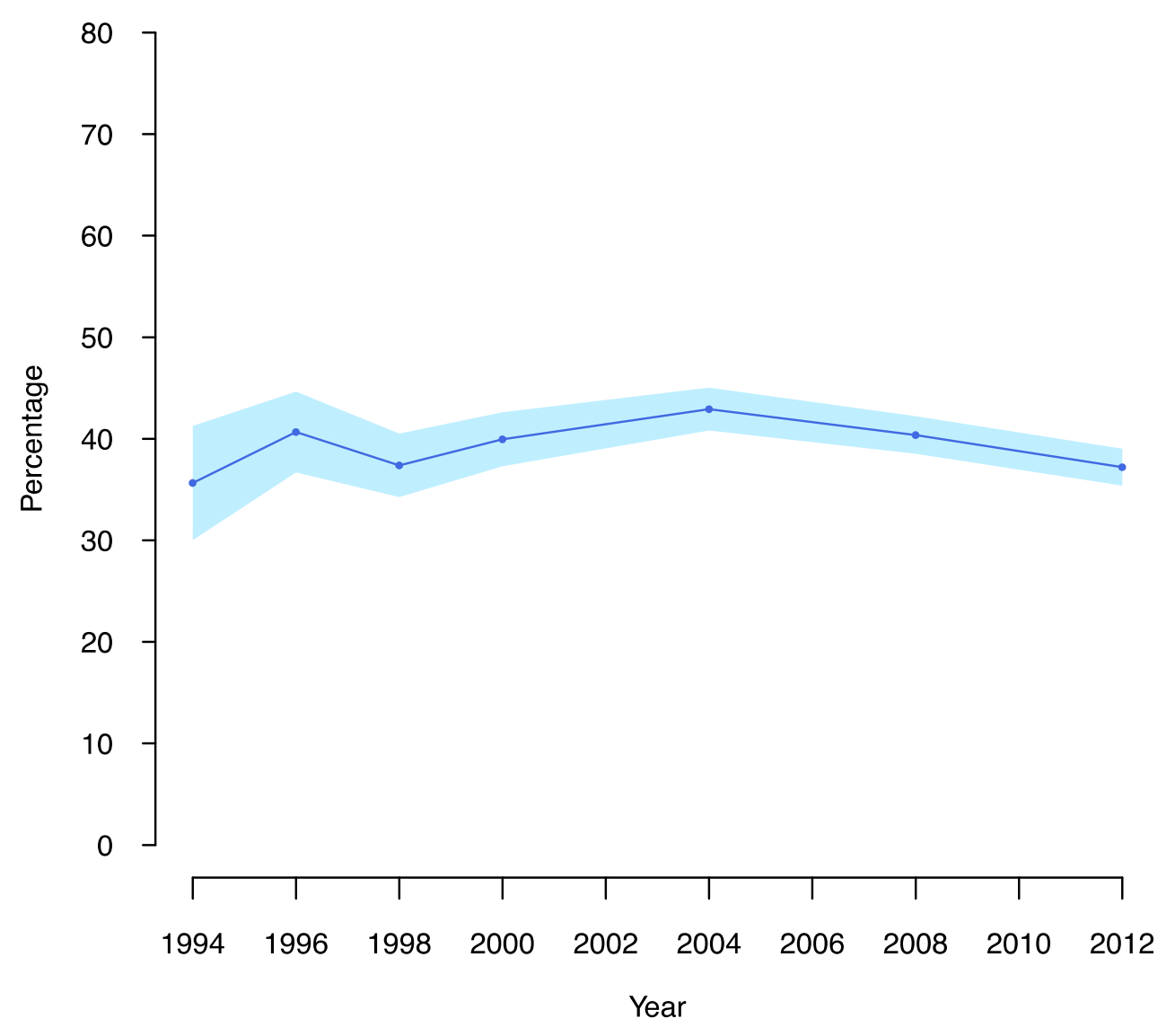

SOURCE: NLSY 1979 Cohort 1994-2012, full sample, restricted to parents of adult children living in own dwellings. $\mathrm{N}=16,108$ cases and $\mathrm{N}=4,761$ individuals

NOTES: Percentage of households with adult children age $18+$ present by year. Estimates include sampling weights and $95 \%$ confidence intervals based on the calculated standard error. 
Figure A2. Mean Financial Assets by Year, NLSY79 Data 1994-2012

\section{Mean Financial Assets by Year}

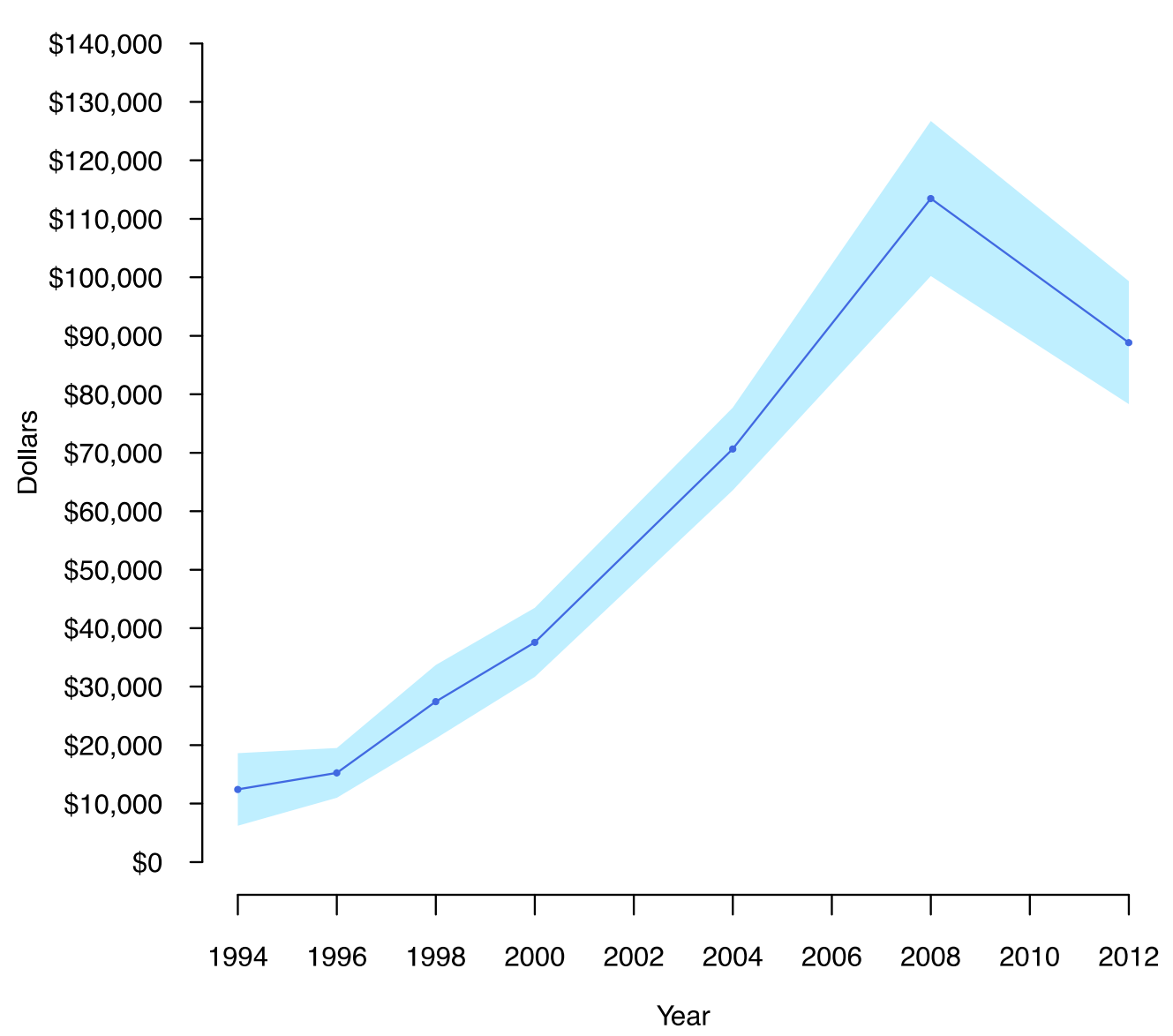

SOURCE: NLSY 1979 Cohort 1994-2012, full sample, restricted to parents of adult children living in own dwellings. $\mathrm{N}=16,108$ cases and $\mathrm{N}=4,761$ individuals

NOTES: Mean financial assets by year for parents of adult children. Estimates include sampling weights and 95\% confidence intervals based on the calculated standard error. 
Figure A3. Mean Savings by Year, NLSY79 Data 1994-2012

\section{Mean Savings by Year}

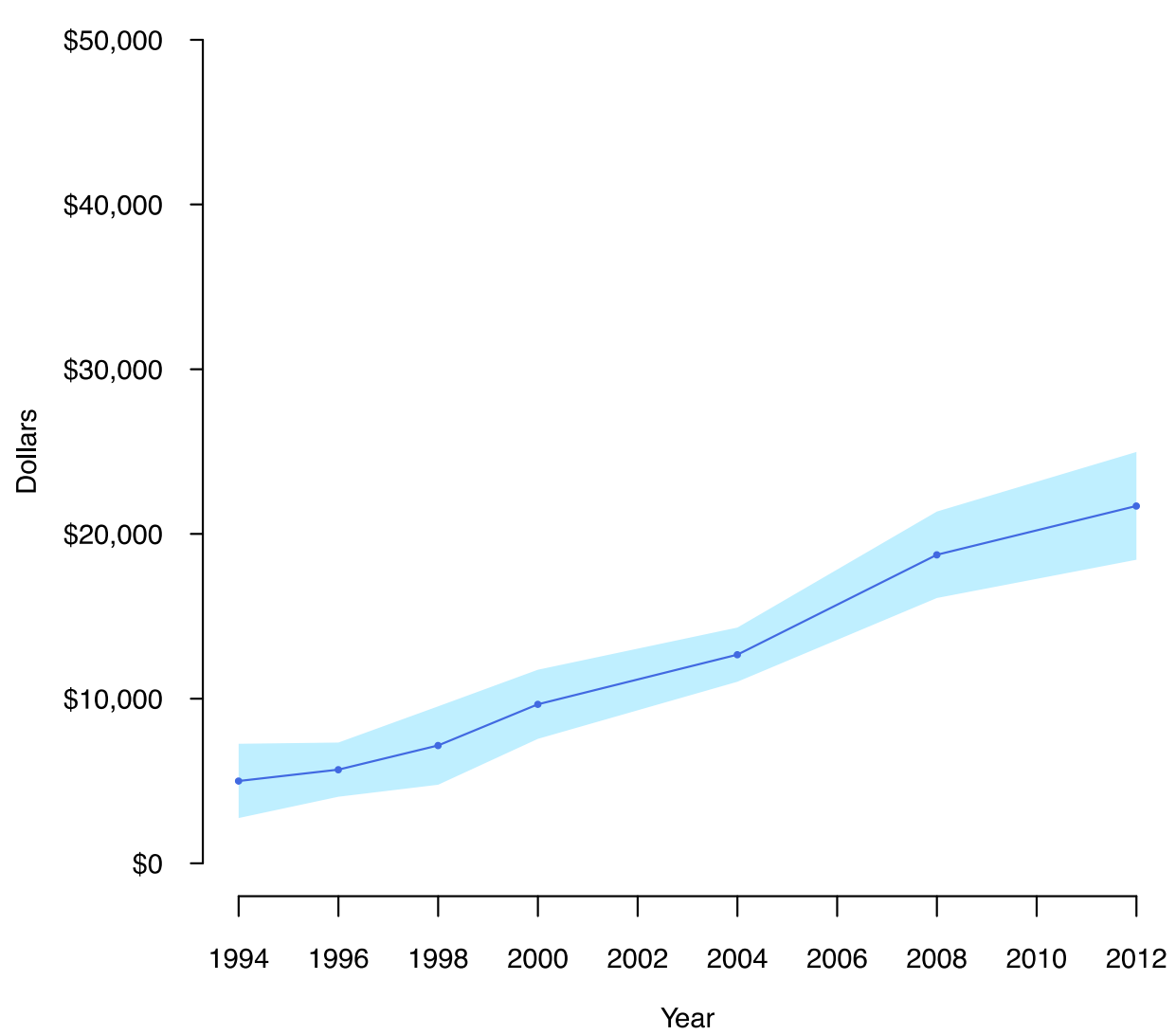

SOURCE: NLSY 1979 Cohort 1994-2012, full sample, restricted to parents of adult children living in own dwellings. $\mathrm{N}=16,108$ cases and $\mathrm{N}=4,761$ individuals

NOTES: Mean total savings by year for parents of adult children. Estimates include sampling weights and $95 \%$ confidence intervals based on the calculated standard error. 